\title{
Subsurface structure of a submarine hydrothermal system in ocean crust formed at the East Pacific Rise, ODP/IODP Site 1256
}

\section{Jeffrey C. Alt}

Department of Geological Sciences, University of Michigan, 1000 North University Avenue, Ann Arbor, Michigan 48109-1005, USA (jalt@umich.edu)

\section{Christine Laverne}

Laboratoire de Pétrologie Magmatique, Faculté des Sciences de Marseille Saint Jérome, Université Paul Cézanne Aix-Marseille III, Case 441, F-13397 Marseille CEDEX 20, France

\section{Rosalind M. Coggon}

Department of Geological Sciences, University of Michigan, 1000 North University Avenue, Ann Arbor, Michigan 48109-1005, USA

Now at Department of Earth Science and Engineering, Imperial College London, Exhibition Road, London SW7 $2 A Z$, $U K$

\section{Damon A. H. Teagle}

School of Ocean and Earth Science, National Oceanography Centre, Southampton, University of Southampton, European Way, Southampton SO14 3ZH, UK

\section{Neil R. Banerjee}

Department of Earth Sciences, University of Western Ontario, London, Ontario N6A 5B7, Canada

\section{Sally Morgan}

Department of Geology, University of Leicester, Leicester LE1 7RH, UK

Also at Borehole Research Group, Department of Geology, University of Leicester, Leicester LE1 7RH, UK

\section{Christopher E. Smith-Duque and Michelle Harris}

School of Ocean and Earth Science, National Oceanography Centre, Southampton, University of Southampton, European Way, Southampton SO14 3ZH, UK

\section{Laura Galli}

Department of Geological Sciences, University of Michigan, 1000 North University Avenue, Ann Arbor, Michigan 48109-1005, USA

[1] ODP/IODP Hole 1256D penetrates an in situ section of ocean crust formed at the East Pacific Rise, through lavas and sheeted dikes and $\sim 100 \mathrm{~m}$ into plutonic rocks. We use mineralogy, oxygen isotopes, and fluid inclusions to understand hydrothermal processes. The lavas are slightly altered at low temperatures $\left(<150^{\circ} \mathrm{C}\right)$ to phyllosilicates and iron oxyhydroxides, with a stepwise increase in grade downward to greenschist minerals in the upper dikes. This resulted from generally upwelling hydrothermal fluids in the dikes mixing with cooler seawater solutions in the lavas, also producing minor metal sulfide mineralization 
in the upper dikes. Alteration grade increases downward in the dikes, with increasing recrystallization to amphibole and loss of metals at higher temperatures $\left(>350^{\circ} \mathrm{C}\right.$ up to $\left.\sim 600^{\circ} \mathrm{C}\right)$. Intrusion of gabbro bodies into the lower dikes resulted in contact metamorphism to granoblastic hornfels at $850^{\circ} \mathrm{C}-900^{\circ} \mathrm{C}$, representing a thermal boundary layer between the axial melt lens and the overlying hydrothermal system. Downward penetration of hydrothermal fluids led to rehydration of granoblastic dikes and plutonic rocks at $\sim 800^{\circ} \mathrm{C}$ down to $<300^{\circ} \mathrm{C}$. Fluid inclusion and oxygen isotope data show that vein quartz formed at $\sim 300^{\circ} \mathrm{C}$ to $>450^{\circ} \mathrm{C}$ from hydrothermal fluids that were affected by supercritical phase separation. Fluids had variable salinities and were enriched in ${ }^{18} \mathrm{O}(+0.4 \%$ o to $+3.5 \%)$ relative to seawater, similar to seafloor vent fluids. Dike margins are brecciated and mineralized, suggesting hydrothermal activity coeval with magmatism. Anhydrite formed mainly in the upper dikes when partly reacted seawater fluids were heated as they penetrated deeper into the system. Low-temperature alteration of the volcanic section continued as cold seawater penetrated along fluid pathways, forming minor iron oxyhydroxides in the rocks. Hydrothermal processes at Site 1256 fit with current models whereby greenschist alteration of dikes at low water/rock ratios is overprinted by fracture-controlled alteration and mineralization by upwelling hydrothermal fluids, a conductive boundary layer above gabbroic intrusions, leaching of metals from dikes and gabbros in the deep "root zone," and stepped thermal and alteration gradients in the basement. The Site 1256 section, however, is intact and retains recharge effects (anhydrite), allowing an integrated view of processes in the subsurface.

Components: 16,400 words, 16 figures, 3 tables.

Keywords: hydrothermal systems; stable isotopes; mid-ocean ridges; ocean drilling.

Index Terms: 1034 Geochemistry: Hydrothermal systems (0450, 3017, 3616, 4832, 8135, 8424); 1041 Geochemistry: Stable isotope geochemistry (0454, 4870); 3036 Marine Geology and Geophysics: Ocean drilling.

Received 26 March 2010; Revised 6 July 2010; Accepted 29 July 2010; Published 15 October 2010.

Alt, J. C., C. Laverne, R. M. Coggon, D. A. H. Teagle, N. R. Banerjee, S. Morgan, C. E. Smith-Duque, M. Harris, and L. Galli (2010), Subsurface structure of a submarine hydrothermal system in ocean crust formed at the East Pacific Rise, ODP/IODP Site 1256, Geochem. Geophys. Geosyst., 11, Q10010, doi:10.1029/2010GC003144.

\section{Introduction}

[2] Submarine hydrothermal systems exert important influences on the composition of seawater and the crust, on the physical properties of the lithosphere, and during recycling in subduction zones [Edmond et al., 1979a; Hofmann and White, 1982; Tatsumi, 1989] (see also summary by Alt [1995]). Mid-ocean ridge hydrothermal systems are studied via diverse approaches, all of which are essential to develop an integrated understanding of these systems. However, direct sampling of ocean crust remains critical to understand the subsurface structure and hydrothermal processes in these systems, as well as to test remote geophysical observations. Ophiolites have provided important inspiration for understanding hydrothermal processes at mid-ocean ridges (MOR) [e.g., Spooner and Fyfe, 1973], but evidence suggests that the hydrothermal alteration of ophiolites is anomalous compared to crust in the major ocean basins [e.g., Bickle and
Teagle, 1992; Alt and Teagle, 2000], and hence the study of in situ oceanic crust remains essential.

[3] Hydrothermal alteration of several sections of upper ocean crust formed at intermediate and fast spreading rates has been well studied. These include tectonic windows at Hess Deep and Pito Deep, formed at fast spreading rates on the East Pacific Rise (EPR), and deep drilling of Hole 504B, formed at intermediate spreading rate in the eastern Pacific [Alt et al., 1986, 1996; Teagle et al., 2003; Gillis et al., 2001; Gillis, 2008; Heft et al., 2008].

[4] In this paper we present results of a study of hydrothermal alteration in a $\sim 1.5 \mathrm{~km}$ section of upper oceanic crust formed at a fast spreading rate at the EPR, as sampled by drilling at ODP/ IODP Site 1256. We document the secondary mineralogy, textural relationships, and distribution of hydrothermal effects in this section, and present fluid inclusion and oxygen isotope analyses of vein minerals. These data are used to understand the overall thermal structure and evolution of hydro- 


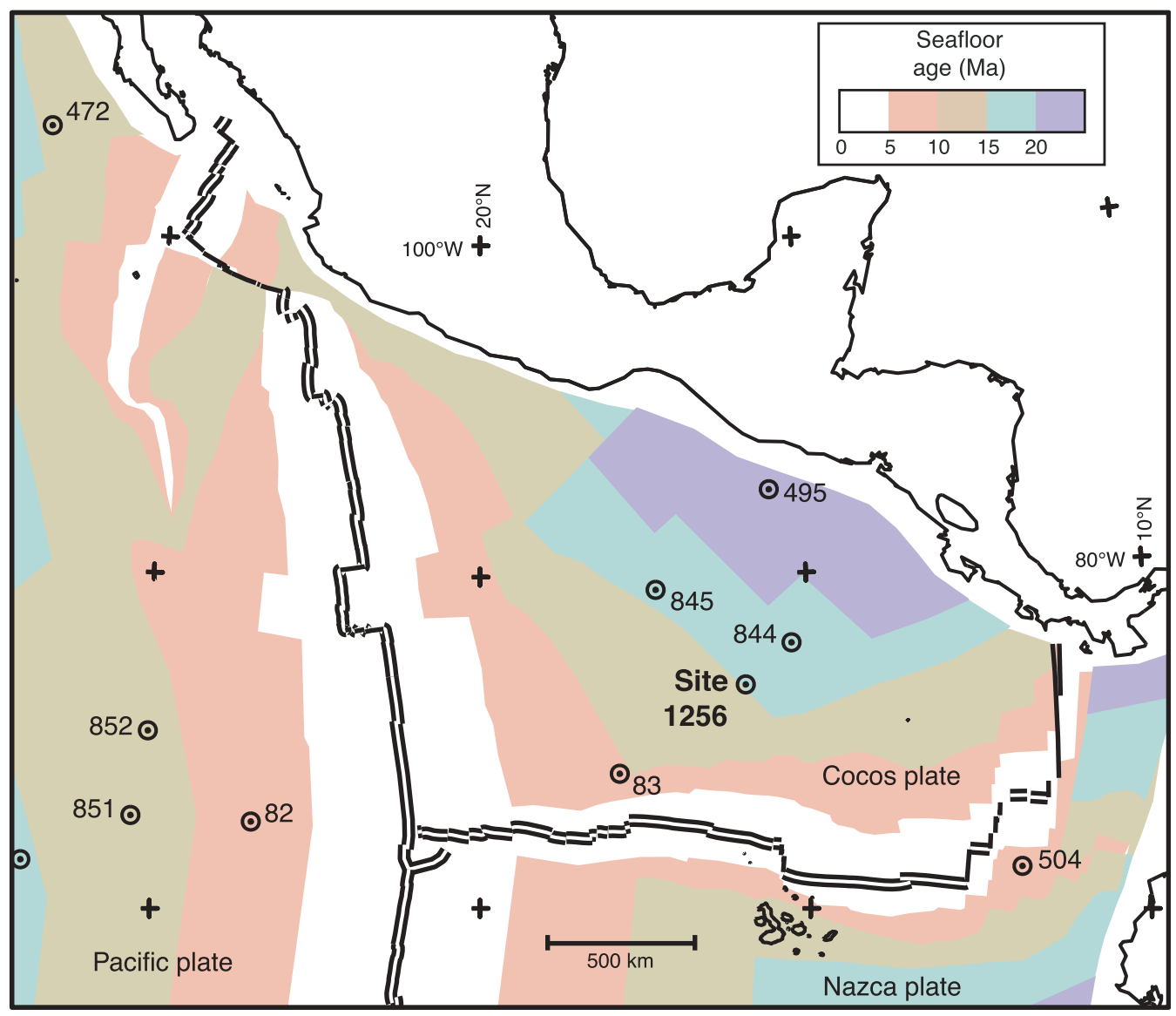

Figure 1. Location of Site 1256 in the eastern Pacific. Isochrons at $5 \mathrm{Myr}$ intervals and selected DSDP and ODP sites are indicated. The wide spacing of 10-20 Myr isochrons to the south reflects the superfast ( $>200 \mathrm{~mm} / \mathrm{yr}$ ) full spreading rate (modified from Wilson et al. [2003]).

thermal alteration at this site. We evaluate our results for Site 1256 in terms of current models for circulation and alteration of the upper oceanic crust at intermediate and fast spreading rates.

\section{Geological Setting and Methods}

\subsection{Hole 1256D Background and Lithostratigraphy}

[5] Site 1256 is located at $6.736^{\circ} \mathrm{N}, 91.934^{\circ} \mathrm{W}$ in the eastern Pacific, in crust that formed at a superfast spreading rate at the EPR $\sim 15 \mathrm{Myr}$ ago (Figure 1) [Teagle and Expedition 309/312 Scientists, 2006; Wilson et al., 2006]. Drilling took place on ODP Leg 206 [Wilson et al., 2003] and IODP Expeditions 309 and 312 [Teagle and Expedition 309/312 Scientists, 2006], and core descriptions are presented in those reports. Hole 1256C penetrates the $250 \mathrm{~m}$ sediment section and extends $72 \mathrm{~m}$ into basement. Hole $1256 \mathrm{D}, \sim 30 \mathrm{~m}$ to the south, was cased though the sediments and $\sim 20 \mathrm{~m}$ into basement [Wilson et al., 2003]. Coring started at $26 \mathrm{~m}$ subbasement (msb), $276 \mathrm{~m}$ below seafloor (mbsf), and extends to a depth of $1507.1 \mathrm{mbsf}(1257.1 \mathrm{msb}$; Figure 2) [Teagle and Expedition 309/312 Scientists, 2006; Wilson et al., 2006].

[6] The uppermost basement comprises a $\sim 100 \mathrm{~m}$ thick sequence dominated by a ponded lava flow $>75 \mathrm{~m}$ thick in Hole 1256D but only $32 \mathrm{~m}$ thick in nearby Hole 1256C. The immediately underlying lavas include sheet and massive flows, and minor pillow flows. The upper $284 \mathrm{~m}$ of the volcanic section is interpreted to have formed off axis [Teagle and Expedition 309/312 Scientists, 2006; Tominaga et al., 2009]. Sheet flows and massive lavas erupted at the ridge axis make up the remaining extrusive section down to 1004 mbsf, where a lithologic transition is marked by subvertical intrusive contacts and mineralized breccias. Below $1061 \mathrm{mbsf}$, subvertical intrusive 


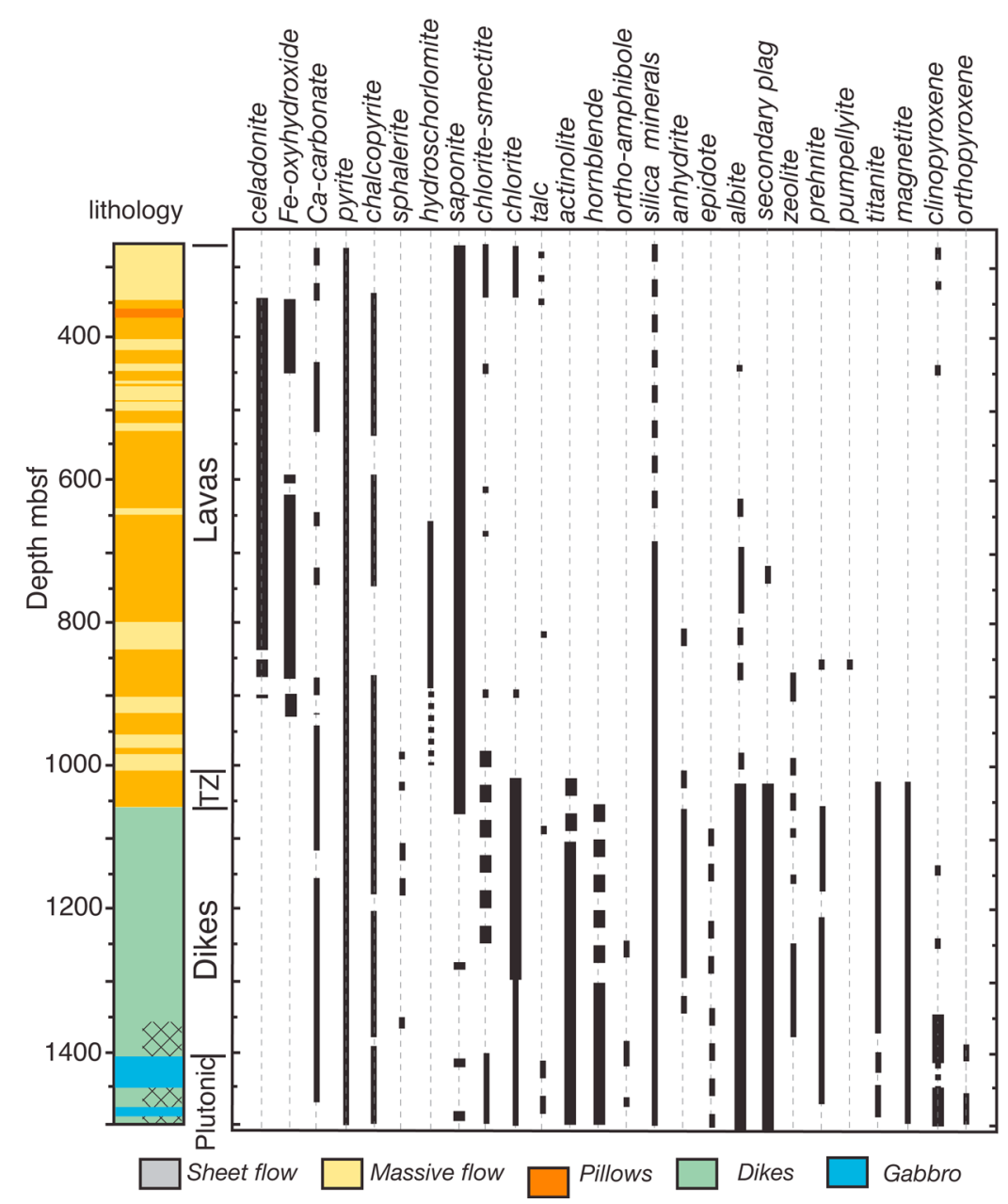

Figure 2. Lithostratigraphy and distribution of secondary minerals versus depth in Hole 1256D. Major secondary phases are shown as thick lines, minor and trace phases are shown as finer lines, and crosshatching indicates granoblastic dikes. Hornblende/actinolite distribution based on textures and electron probe analyses. Shipboard lithostratigraphy from Teagle and Expedition 309/312 Scientists [2006]. Mineral distributions based on study of shipboard thin sections [Wilson et al., 2003; Teagle and Expedition 309/312 Scientists, 2006] and this study.

contacts indicate a $\sim 350 \mathrm{~m}$ thick sheeted dike complex [Teagle and Expedition 309/312 Scientists, 2006; Tominaga et al., 2009]. Some rocks have doleritic textures, and many are cut by subvertical dikes with common brecciated and mineralized chilled margins. The lower $\sim 60 \mathrm{~m}$ of the sheeted dike complex is recrystallized to granoblastic textures by contact metamorphism.

[7] The plutonic complex begins at 1407 mbsf. Two gabbro bodies were penetrated, with a $52 \mathrm{~m}$ thick upper gabbro separated from a $24 \mathrm{~m}$ thick lower gabbro by a $24 \mathrm{~m}$ screen of dikes that was recrystallized by contact metamorphism (Figure 2). The upper gabbro comprises gabbros, oxide gabbros, quartz-rich oxide diorites and small trondjhemite dikelets. The lower gabbro comprises gabbro, oxide gabbro, and lesser orthopyroxene bearing gabbro and trondjhemite [Teagle and Expedition 309/312 Scientists, 2006]. Contacts with the dike screen are intrusive, with partly resorbed, stoped dike clasts within the margins of the lower gabbro. The lowermost rock recovered from the hole is a highly altered actinolite-bearing basaltic dike that postdates the intrusion of the lower gabbro.

[8] Flows and dikes show a wide range of fractionation, from $\mathrm{MgO} \sim 4.5$ to $10 \mathrm{wt} \%$ (mostly 5.8-9.0) [Teagle and Expedition 309/312 Scientists, 2006; Wilson et al., 2006]. The ranges of most major and many minor element concentrations are similar to those of the northern East Pacific Rise [Teagle and 

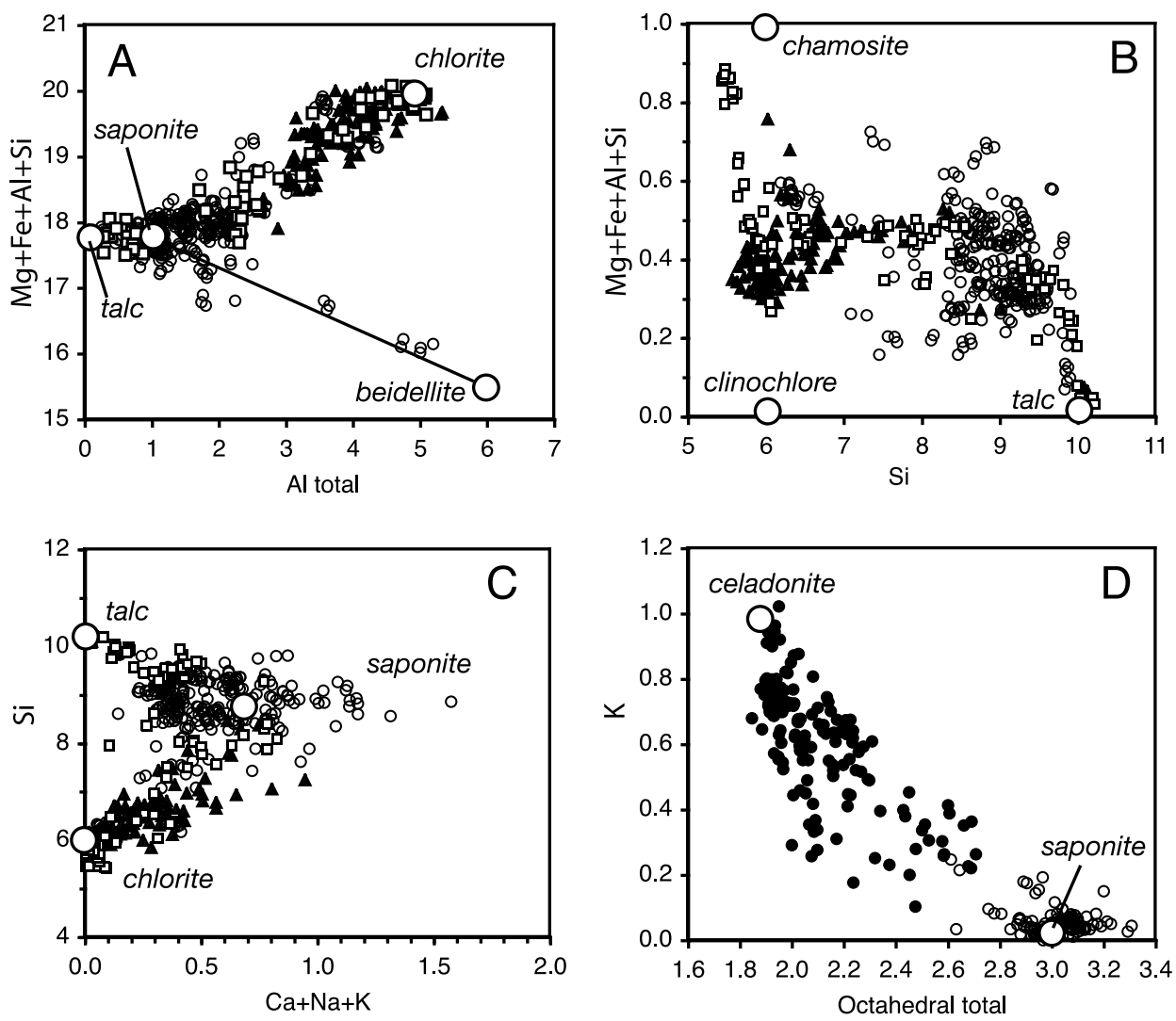

Figure 3. Phyllosilicate compositions. Formulas calculated as chlorites (layer charge $=56$ ) in Figures $3 \mathrm{a}-3 \mathrm{c}$. (a) Talc, saponite, and beidellite end-members are indicated. Smectite-chlorite occupies trend from saponite to chlorite [after Schiffman and Fridleifsson, 1991]. (b) Chlorite classification diagram illustrating variable compositions of chlorites (between chamosite and clinochlore) and trend to higher Si contents of smectite-chlorite, saponite, and talc. (c) Trends from smectite at variable and high interlayer cation contents to chlorite at low contents of Si and interlayer cations and to talc at high $\mathrm{Si}$ and low interlayer contents. (d) Trend from celadonite at high $\mathrm{K}$ content (0.8-1.0) to saponite at low $\mathrm{K}$ and high octahedral contents results from variable mixtures of celadonite and smectite. Formulas calculated as smectites (layer charge $=22$ ). Circles, lavas (solid, celadonite; open, saponite); filled triangles, dikes; open squares, gabbro.

Expedition 309/312 Scientists, 2006; Wilson et al., 2006], indicating similar processes at the superfast spreading ridge that formed Site 1256 and the modern EPR. Gabbro compositions span a range similar to the flows and dikes, but are on average more primitive (mean $\mathrm{MgO} \sim 8 \mathrm{wt} \%$ versus $7.2 \mathrm{wt} \%$ for flows and dikes).

\subsection{Methods}

[9] Alteration petrography and secondary mineralogy were studied by transmitted and reflected light microscopy, with percent secondary phases estimated visually. Compositions of secondary minerals were determined by electron microprobe at The University of Michigan and Ifremer (Brest, France), with methods given by Alt and Laverne [2006]. Electron probe data presented in Figures 3-6, 9, and 10 are given in the auxiliary material. ${ }^{1}$ Selected phyllosilicate veins were analyzed by X-ray diffraction at the University of Michigan. Oriented powder mounts were scanned with a Scintag automated diffractometer using $\mathrm{Cu} \mathrm{K} \alpha$ radiation, and a scan rate of $2^{\circ} 2 \theta / \mathrm{min}$, after air drying and glycolation treatments.

[10] Secondary minerals for oxygen isotope analyses were separated from veins by crushing and hand picking, and purity and mineralogy were checked by X-ray diffraction and visual inspection. Oxygen isotope analyses were carried out at the University of Michigan by reacting samples with $\mathrm{BrF}_{5}$ in externally heated nickel reaction vessels [Clayton

\footnotetext{
${ }^{1}$ Auxiliary materials are available at $\mathrm{ftp} / / \mathrm{ftp}$.agu.org/apend/gc/ $2010 \mathrm{gc003144.}$
} 


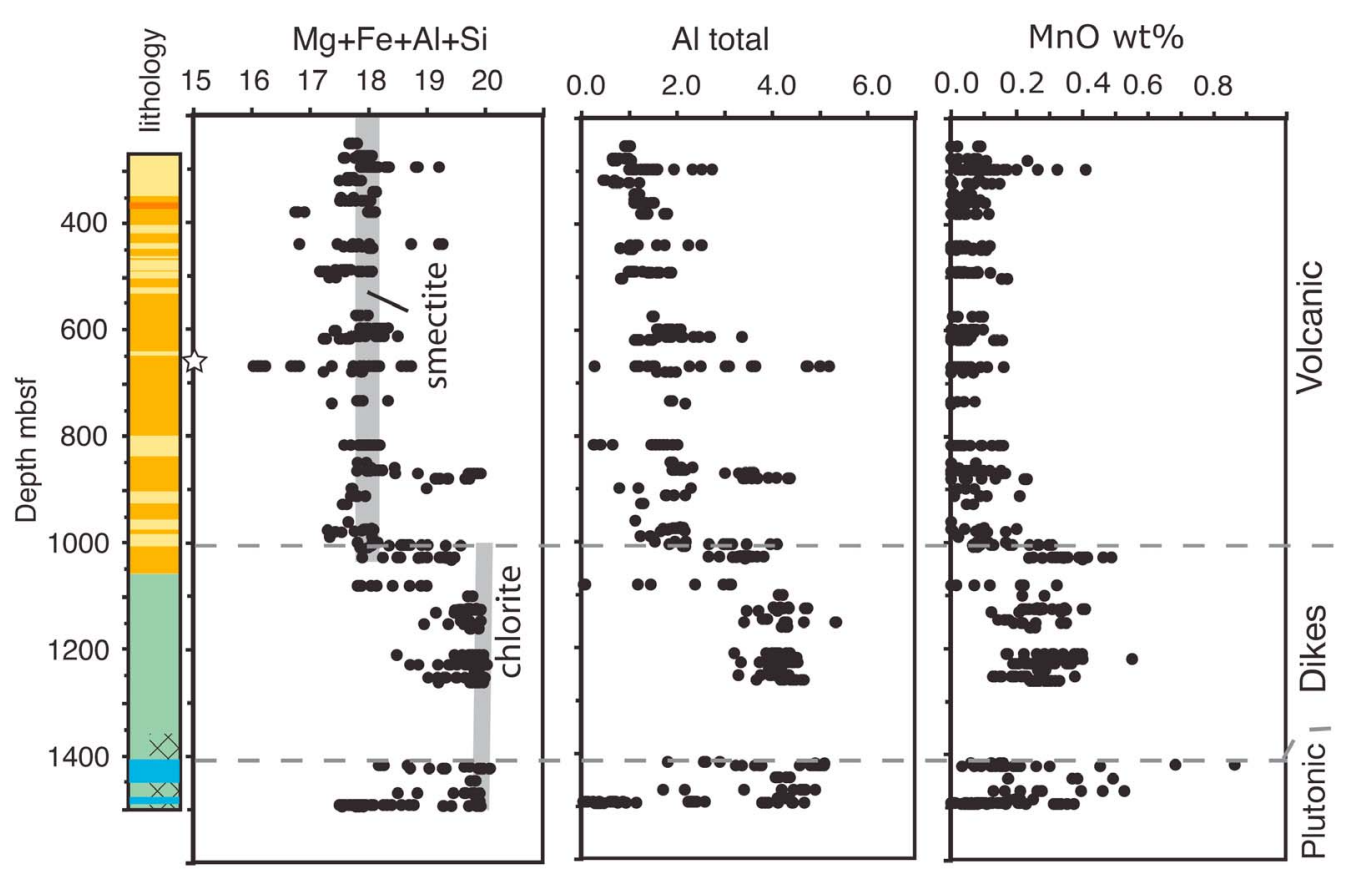

Figure 4. Compositions of phyllosilicates versus depth. Volcanic section is dominated by smectite, with local smectite-chlorite (high $\mathrm{Mg}+\mathrm{Fe}+\mathrm{Al}+\mathrm{Si}$ and $\mathrm{Al}$ contents at $\sim 290,450$, and $\sim 880 \mathrm{mbsf}$ ). Beidellite in the intensely altered basalt at $648 \mathrm{mbsf}$ (star) is characterized by low $\mathrm{Mg}+\mathrm{Fe}+\mathrm{Al}+\mathrm{Si}$ and high Al. Stepwise change from saponite to chlorite occurs at top of lavas-dikes transition (at $1004 \mathrm{mbsf}$ ). Smectite-chlorite in dikes and plutonic section indicated by low $\mathrm{Al}$ and $\mathrm{Mg}+\mathrm{Fe}+\mathrm{Al}+\mathrm{Si}$ contents relative to chlorite. Talc is present at $\mathrm{Al}=0 \mathrm{wt} \%$. Lithology as in Figure 2.

and Mayeda, 1963], and converting $\mathrm{O}_{2}$ to $\mathrm{CO}_{2}$ gas by reaction with heated carbon rods. Oxygen isotope ratios were measured using a Finnigan Delta-S mass spectrometer. NBS 28 quartz run with sample unknowns had a mean $\delta^{18} \mathrm{O}$ value of $9.6 \%$ o $( \pm 0.2,1 \sigma)$ compared to the accepted value of $9.58 \%$. Anhydrite data are corrected using NBS $127 \mathrm{BaSO}_{4}$, which was run concurrently with unknowns, and sulfate oxygen data were normalized to a value of $9.34 \%$ o for NBS 127 [Gonfiantini et al., 1995].

[11] Microthermometric measurements on fluid inclusions in quartz were made at University of Leeds, using a Linkam THMSG 600 heating-freezing stage. Samples include four quartz veins ( \pm minor chlorite, prehnite, amphibole, laumontite, sulfides) in dikes and gabbros, one quartz-filled vug from the dike section, one plagiogranite and one tonalite vein, and groundmass quartz from an oxide gabbro. Freezing temperature and melting temperature of the solid were measured first, followed by heating measurements, including daughter crystal dissolution (Tm) and homogenization temperature $(\mathrm{Th})$. Precision and accuracy were $\pm 0.2^{\circ} \mathrm{C}$ below $0^{\circ} \mathrm{C}$ and $\pm 2^{\circ} \mathrm{C}$ above $0^{\circ} \mathrm{C}$. Salinity was estimated using freezing point depression assuming a pure $\mathrm{NaCl}$ solution and is reported as wt \% $\mathrm{NaCl}$ equivalent [Bodnar, 2003].
Using measured salinities, estimated pressures, and data from Bodnar [2003], homogenization temperatures of two-phase liquid-vapor fluid inclusions were corrected for assumed hydrostatic pressure (350-410 bars, see auxiliary material), yielding trapping temperatures (Tt). Pressures were estimated based on depth to the seafloor and depth below seafloor.

\section{Results}

\subsection{Hydrothermal Alteration}

[12] Documentation of hydrothermal alteration is divided into sections below based on mineralogy and lithology: the volcanic section; transition zone and sheeted dikes; the granoblastic dikes and dike screens; and plutonic rocks.

\subsubsection{Volcanic Section}

\subsubsection{Background Alteration}

[13] The volcanic section exhibits a pervasive background alteration where the rocks are dark gray and slightly to moderately altered $(2 \%-20 \%$, typically 

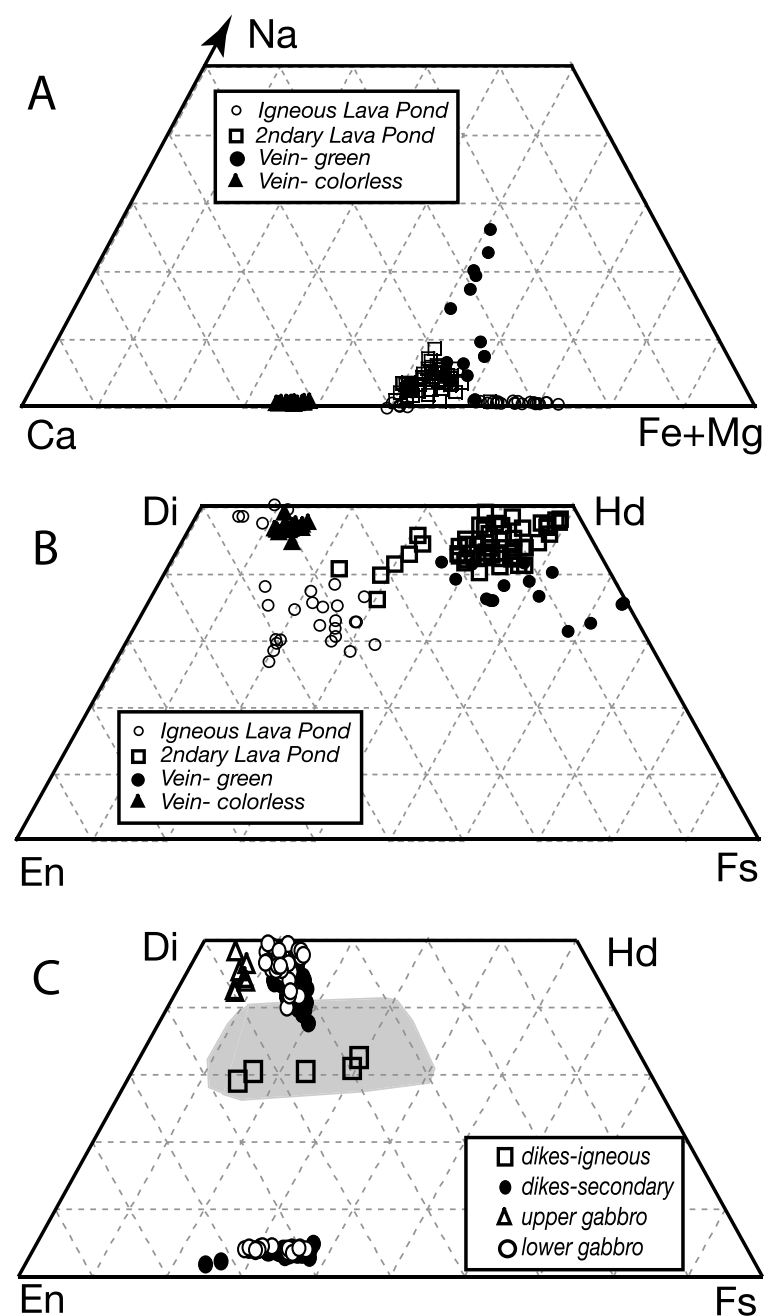

Figure 5. Compositions of pyroxenes. ( $a$ and $b$ ) Pyroxenes in lavas and sheeted dikes. Igneous clinopyroxenes in the lava pond have compositions similar to the rest of the lavas and dikes but range to high-Ca diopside. Secondary hedenbergite reaction rims in the lava pond have higher $\mathrm{Fe}, \mathrm{Ca}$, and $\mathrm{Na}$ compared to igneous augites. Green vein clinopyroxenes in lavas (at $445.60 \mathrm{mbsf}$, sample 26R2, 18-21) and dikes (at $1245.75 \mathrm{mbsf}$, 168R3, 78-82) are aegerine-augite, with elevated $\mathrm{Na}$ and Fe compared to igneous augite. Colorless vein clinopyroxene in a dike (1143.54 mbsf, 146R2, 48-52) is diopside. (c) Compositions of pyroxenes in granoblastic dikes and gabbros. Field for igneous augites in lavas and dikes shown for comparison (gray field [from Dziony et al., 2008]). Secondary pyroxenes in the granoblastic dikes are enstatite and diopsidic clinopyroxene. Also shown are pyroxene compositions in gabbros. Clinopyroxenes and orthopyroxenes in the lower gabbro have textures and compositions similar to those in the granoblastic dikes (see section 3.1.4). $\sim 10 \%$ ). Saponite replaces olivine and interstitial glass and fills pore space, with common disseminated secondary sulfides. Basaltic glass at flow margins is fresh to variably altered to saponite and trace phillipsite. The most common phyllosilicate in the volcanic section is saponite (Mg-rich, trioctahedral smectite). Saponites have noninterlayer
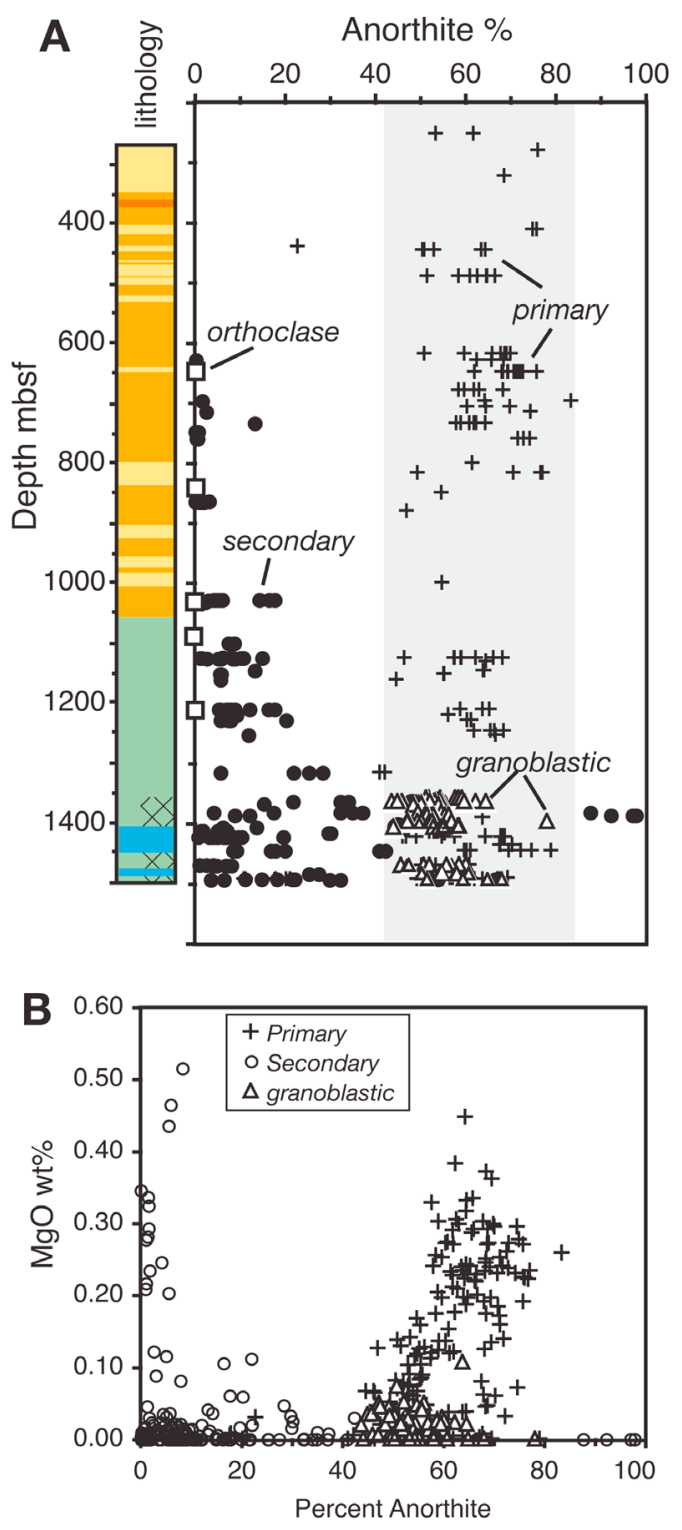

Figure 6. Compositions of feldspars. (a) Percent anorthite versus depth. Locations of orthoclase are indicated. Shading indicates compositions of igneous plagioclase (excluding sodic rims on some crystals). (b) $\mathrm{MgO}$ contents of igneous feldspars decrease with decreasing $\%$ An. Secondary plagioclase mainly has low MgO contents, except for some low-An plagioclase. Lithology as in Figure 2. 
cation $(\mathrm{Mg}+\mathrm{Fe}+\mathrm{Al}+\mathrm{Si})$ contents of $\sim 17.5-18$ and elevated interlayer cation contents (Figure 3). Compositions range toward talc, with low $\mathrm{Al}$ and interlayer cation contents (Figure 3). Variable amounts of chlorite are present locally, as indicated by elevated contents of $\mathrm{Mg}+\mathrm{Fe}+\mathrm{Al}+\mathrm{Si}$ and decreasing Si and interlayer cations (Figures 3 and 4 ), and by X-ray diffraction. Dark gray $\mathrm{mm}$ - to $\mathrm{cm}$-scale alteration patches around pores filled with saponite and silica minerals in the coarser-grained portions of thick flows are more altered, and contain $~ 50 \%$ secondary minerals. The central portion of the thick ponded lava at the top of the basement contains late magmatic/hydrothermal effects, including secondary $\mathrm{Na}$-hedenbergite reaction rims on primary augite (Figure 5) [Laverne et al., 2007].

[14] A significant change occurs below 627 mbsf, where secondary albite, saponite, and chloritesmectite locally replace the cores of plagioclase phenocrysts and microphenocrysts (Figures 4 and 6). Below 660 mbsf, titanomagnetite is more altered and hydroschorlomite appears (Ti-rich hydrogarnet) [Laverne et al., 2006].

[15] A unique $41 \mathrm{~cm}$ interval at $648 \mathrm{mbsf}$ is highly (80\%-90\%) altered. Olivine, clinopyroxene, and plagioclase are replaced by beidellite, celadonite, $\mathrm{K}$-feldspar and iron oxyhydroxide, imparting bluegreen and brick red colors to the rock. These minerals plus quartz and carbonate also fill vugs and pore space. The Al-rich smectite beidellite appears in trends toward decreasing $\mathrm{Mg}+\mathrm{Fe}+\mathrm{Al}+\mathrm{Si}$ and increasing total $\mathrm{Al}$ in Figure 3.

[16] Pumpellyite is present in a $>70 \mathrm{~cm}$ interval of basalt at 864 mbsf, where it fills veins and pores with albite, smectite/talc, celadonite, laumontite, minor prehnite, calcite, and titanite, and locally replaces olivine.

\subsubsection{Veins and Vein-Related Alteration}

[17] Veins make up $1 \%$ by volume of the volcanic section with an average of 23 veins $/ \mathrm{m}$ of core. Saponite-bearing veins are the most abundant, commonly containing minor pyrite. Celadonite \pm iron oxyhydroxide veins are a factor of 10 less abundant. Compositions of celadonite range from celadonite to glauconite [Alt and Laverne, 2006]. Trends of decreasing $\mathrm{K}$ with increasing tetrahedral $\mathrm{Al}$ and octahedral $\mathrm{Mg}$ indicate the presence of variable mixtures with smectite (Figure 3). Also present in veins are silica minerals (opal, chalcedony, and quartz) and small amounts of calcium carbonate. Early green aegerine-augite in a vein at 445.60 (Figure 5) probably formed during initial seawater penetration into cooling basalt [Laverne, 1987]. Petrographic relationships indicate early formation of celadonite \pm iron oxyhydroxides in veins, followed by saponite, and then silica minerals and carbonate. Anhydrite is present locally in veins (around 825 mbsf; Figure 2), and generally postdates associated quartz, pyrite and local calcite.

[18] Alteration halos along veins make up 3.5\% of the core (Figure 7a). These are present throughout most of the volcanic section, but are more abundant at 350-450 and 630-820 mbsf [Wilson et al., 2003]. The halos are typically 1 to $10 \mathrm{~mm}$ wide, but range up to $30 \mathrm{~mm}$ wide. Dark halos are characterized by celadonite + minor later saponite, but iron oxyhydroxide can impart a reddish color to the rock. In rare cases, narrow brown alteration halos contain iron oxyhydroxides as the only secondary mineral.

[19] Below 850 mbsf halos are characteristically 0.1 to $2 \mathrm{~mm}$ greenish to gray zones along saponite veins, where the rock is moderately to highly altered to saponite or chlorite-smectite. Below $\sim 950 \mathrm{mbsf}$, halos are characterized by pyrite and minor chalcopyrite disseminated in the rock along narrow $(<1 \mathrm{~mm})$ alteration halos.

\subsubsection{Breccias}

[20] Breccias make up 2\% of the core, although wireline logging suggests they are more abundant [Tominaga et al., 2009]. Hyaloclastites make up $90 \%$ of breccias and consist of fresh and altered glass clasts in a matrix of saponite and trace quartz. Glass fragments are variably altered to palagonite, saponitic smectite, and trace pyrite. Local basalt breccias are cemented by saponite, local celadonite, chalcedony, red jasper, quartz, pyrite, and minor anhydrite.

\subsubsection{Transition Zone and Sheeted Dikes}

[21] The transition zone and sheeted dikes are characterized by greenschist and subgreenschist minerals in rocks and veins. Hydrothermal alteration is manifest as (1) pervasive but variable background recrystallization; (2) alteration halos along veins; (3) highly altered patches around vugs; and (4) local metal sulfide mineralization in breccias, dike margins, and veins. 

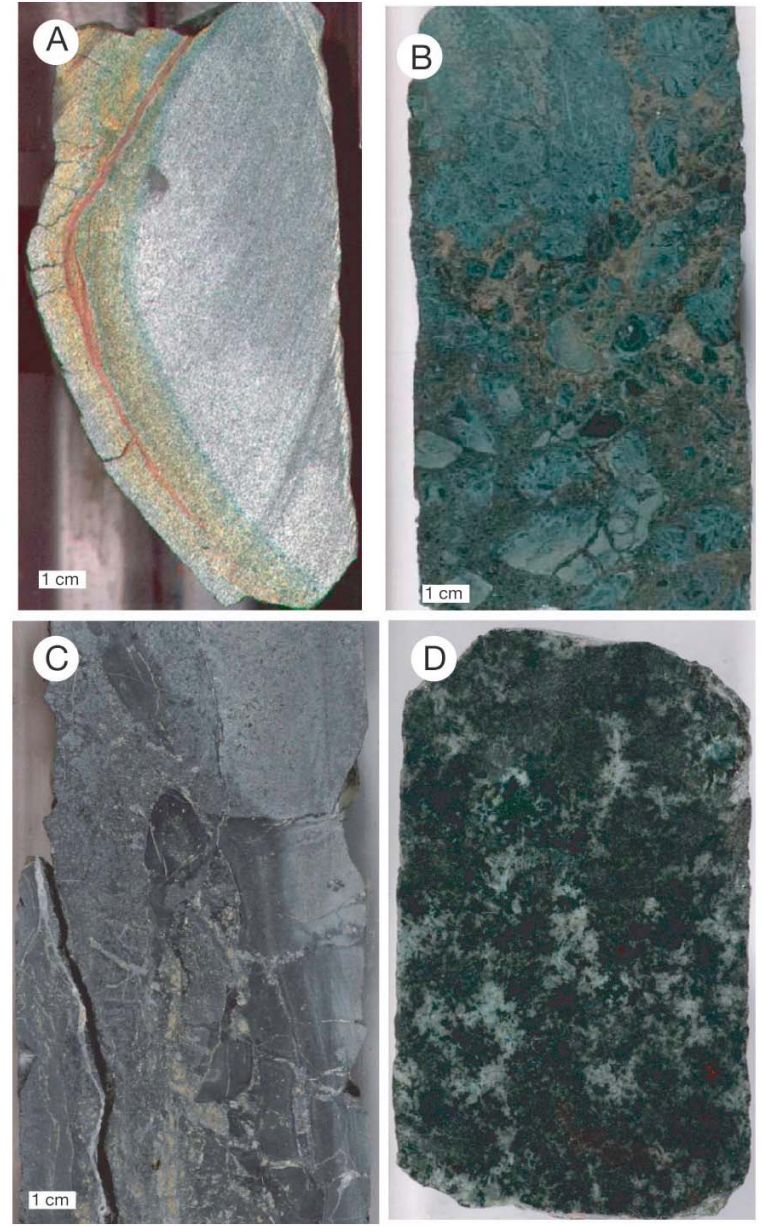

Figure 7. Characteristic alteration features in lavas and dikes. (a) Mixed dark + brown alteration halo along $2 \mathrm{~mm}$ vein of celadonite + iron oxyhydroxide + late saponite (sample 206-1256D-61R-1, 50-59 cm, $678.55 \mathrm{mbsf}$ ). Alteration halos are mainly dark gray to green and black but range to brown and reddish. The degree of alteration is similar to the host rock. (b) Mineralized hyaloclastite breccia (at $1028 \mathrm{mbsf}$ ). Clasts of aphyric cryptocrystalline basalt and light green altered glass in a matrix of chlorite, albite, and pyrite (brownish in photo), with local sphalerite, quartz, and K-feldspar (309-1256D-122R-1, 68-79 cm). (c) Brecciated and mineralized dike margin. Dike on right intrudes host dike on left, with contact characterized by brecciation, flow structures, and multiple veins. (3091256D-140R-1, 41-59 cm, 1114.12 mbsf). Host rock is altered to actinolite, chlorite, titanite, and albite. A vein of chlorite + quartz + pyrite + magnetite + trace chalcopyrite is cut by a $1 \mathrm{~mm}$ vein of quartz + chalcopyrite + magnetite + actinolite. The host rock is cut by numerous $0.2 \mathrm{~mm}$ veins of quartz, sulfides, chlorite, and actinolite. (d) Gabbro exhibiting typical patchy texture. Darker areas of ophitic clinopyroxene enclosing plagioclase are less altered than coarser grained, more felsic material between, imparting patchy appearance to rock.

\subsubsection{Background Alteration}

[22] Beginning at the top of the lithologic transition zone (1004 mbsf), rocks are variably $(1 \%-80 \%$; commonly $30 \%-50 \%$ ) altered to greenschist and subgreenschist assemblages. Clinopyroxene commonly appears cloudy as the result of partial replacement by fibrous amphibole plus tiny $(<1-2 \mu \mathrm{m})$ grains of magnetite (Figures $8 \mathrm{a}$ and $8 \mathrm{~b}$ ). Plagioclase phenocrysts and groundmass are variably replaced by albite-oligoclase $\left(\mathrm{An}_{0-20}\right)$, chlorite, and chlorite-smectite. Small amounts of prehnite, anhydrite, epidote, laumontite and rare calcite occur locally as grains or patches partly replacing plagioclase. Olivine and interstitial areas are variably recrystallized to chlorite-smectite, chlorite, and minor amphibole. Titanomagnetite is partly replaced by titanite, and disseminated pyrite and chalcopyrite are common.

[23] Chlorite is a major alteration phase above 1300 mbsf, but amphibole becomes dominant below this depth (Figure 2). Below 1300 mbsf clinopyroxene is more intensely recrystallized to amphibole + magnetite, plagioclase is partly altered to albite-oligoclase and minor anhydrite, and titanomagnetite is more highly altered to titanite (Figures $8 \mathrm{c}$ and $8 \mathrm{~d}$ ).

[24] Compositions of amphiboles down to $1350 \mathrm{mbsf}$ range from actinolite and minor ferroactinolite to $\mathrm{Mg}$ hornblende, and include local $\mathrm{Fe}-\mathrm{Mg}$ amphiboles (Figures 9 and 10). Data are sparse in the upper dikes (in part because of the fibrous nature of amphibole and patchy replacement of pyroxene), but suggest actinolite in the transition zone and a wider range of composition in the dikes. Local Fe-Mg amphiboles replace interstitial material (e.g., at $1252 \mathrm{mbsf}$ ) and pyroxene (e.g., along with actinolite and $\mathrm{Mg}$-hornblende along a chlorite + quartz + titanite vein at 1256 mbsf; Figure 10).

[25] Epidote compositions are variable, with $\mathrm{Fe} / \mathrm{Fe}+$ $\mathrm{Al}=0.17-0.33$ (Figure 10). Secondary plagioclase in the dikes is albite to oligoclase (mostly $\mathrm{An}_{0}-\mathrm{An}_{20}$, but ranging up to $\mathrm{An}_{28}$ at $1315 \mathrm{mbsf}$; Figure 6). Secondary plagioclase tends to have low $\mathrm{MgO}$ contents, although some albite has high $\mathrm{MgO}$ (Figure 6).

\subsubsection{Veins, Vein-Related Alteration Halos, and Isolated Patches}

[26] Veins comprise $0.9 \%$ of the dikes, at a frequency of $\sim 30$ veins $/ \mathrm{m}$. Chlorite is the most common vein filling, although quartz, pyrite, chalcopyrite, actinolite, prehnite, laumontite, and calcite are also common. Secondary clinopyroxene was identified 

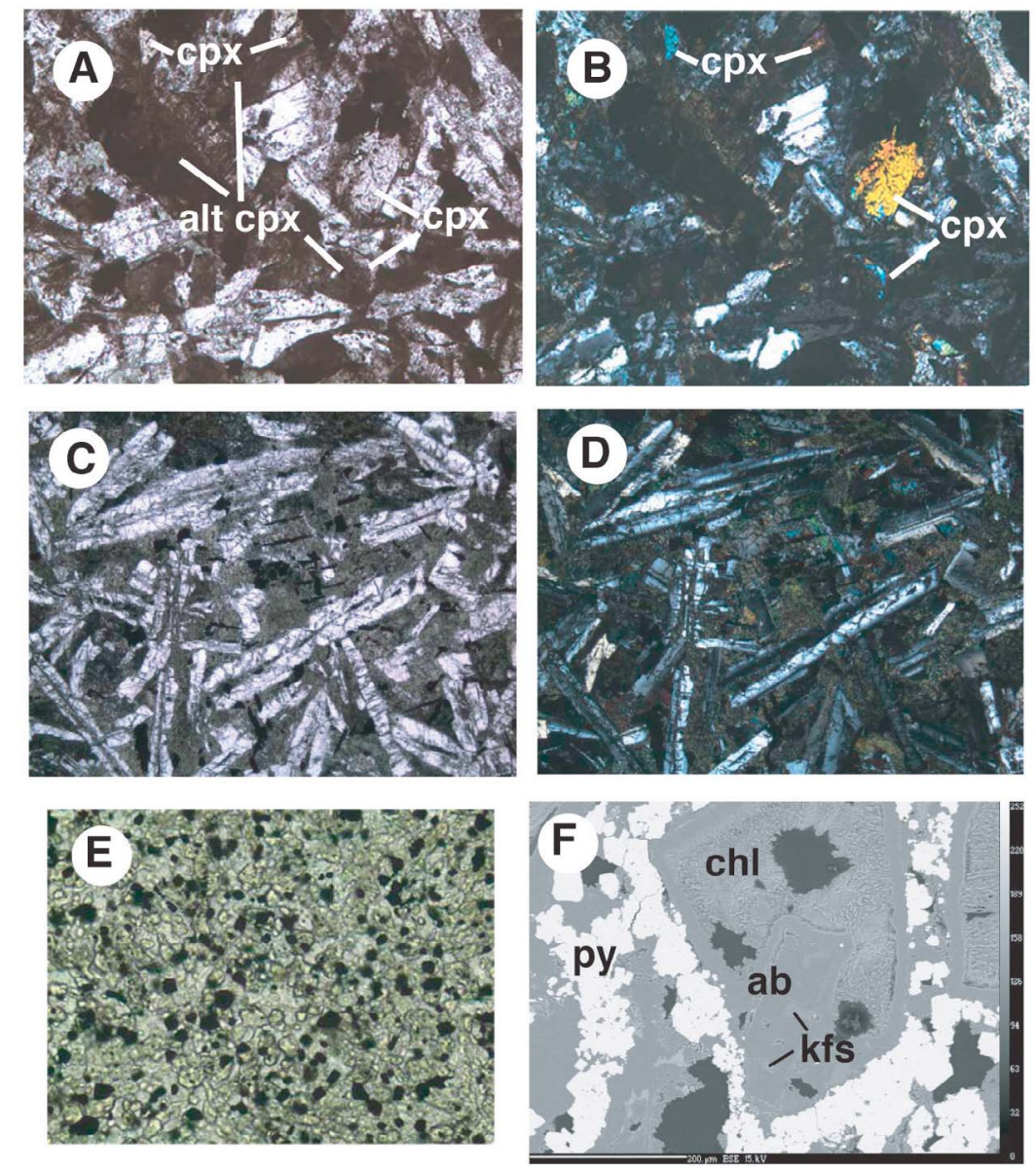

Figure 8. Thin section photomicrographs of characteristic alteration effects in sheeted dikes. (a) Background alteration in upper dikes, with clinopyroxene partly corroded and altered to "dusty" clinopyroxene/actinolite+magnetite on the left and with unaltered clinopyroxene on the right (sample 312-1256D-176R-1, 8-12 cm; 1276.18 mbsf) (planepolarized light; field of view $(\mathrm{FOV})=1.12 \mathrm{~mm}$ ). (b) Same as Figure 8a but with cross-polarized light. (c) Background alteration in lower dikes, highly altered basaltic dike with clinopyroxene replaced by greenish amphibole \pm magnetite (black) (sample 312-1256D-189R-1, 68-69 cm; $1334.58 \mathrm{mbsf}$ ) (plane polarized light, FOV = 4.5 mm). (d) Same as Figure 8c but with cross-polarized light. (e) Granoblastic dike, with equigranular assemblage of plagioclase, clinopyroxene, magnetite, and ilmenite (plane-polarized light; FOV = $0.6 \mathrm{~mm}$ ) (sample 312-1256D-205R-1, 10-14 cm; $1382.20 \mathrm{mbsf}$ ). (f) BSE image of mineralized breccia in Figure 7b. Glass clast is replace by chlorite, albite, K-feldspar (lighter gray), and pyrite, in a matrix of the same minerals. Scale at bottom left is $200 \mu \mathrm{m}$.

in two veins (Figure 5): at 1143.54 mbsf colorless diopside occurs along the walls of a vein; at $1245.75 \mathrm{mbsf}$ green aegerine-augite occurs with titanite, hydro-andradite, local epidote, and late anhydrite. Vein relationships indicate a general sequence of mineral formation: (1) chlorite, amphibole, titanite, and pyrite veins can be overprinted by (2) veins of quartz, chlorite, epidote, pyrite, chalcopyrite and rare sphalerite, and (3) late vein minerals include anhydrite, prehnite, laumontite, and calcite [Teagle and Expedition 309/312 Scientists, 2006]. Anhydrite is present locally in veins below $1000 \mathrm{mbsf}$, but is most abundant from 1100 to 1200 mbsf (Figure 2).
[27] Rock texture and proximity to veins and pore space influence recrystallization of the rocks, with medium grained rocks being more intensely recrystallized than finer grained rocks. Alteration halos, $1-11 \mathrm{~mm}$ wide, along veins make up $4 \%$ of the core, and are more intensely recrystallized $(10 \%-100 \%)$ than the host rock. Alteration patches comprise $1.4 \%$ of the core. Millimeter-scale pores are filled with quartz, chlorite, actinolite needles, pyrite, prehnite and laumontite (and rare sphalerite), and are surrounded by $\mathrm{cm}$-scale, highly altered $(60 \%-100 \%)$, alteration halos. 

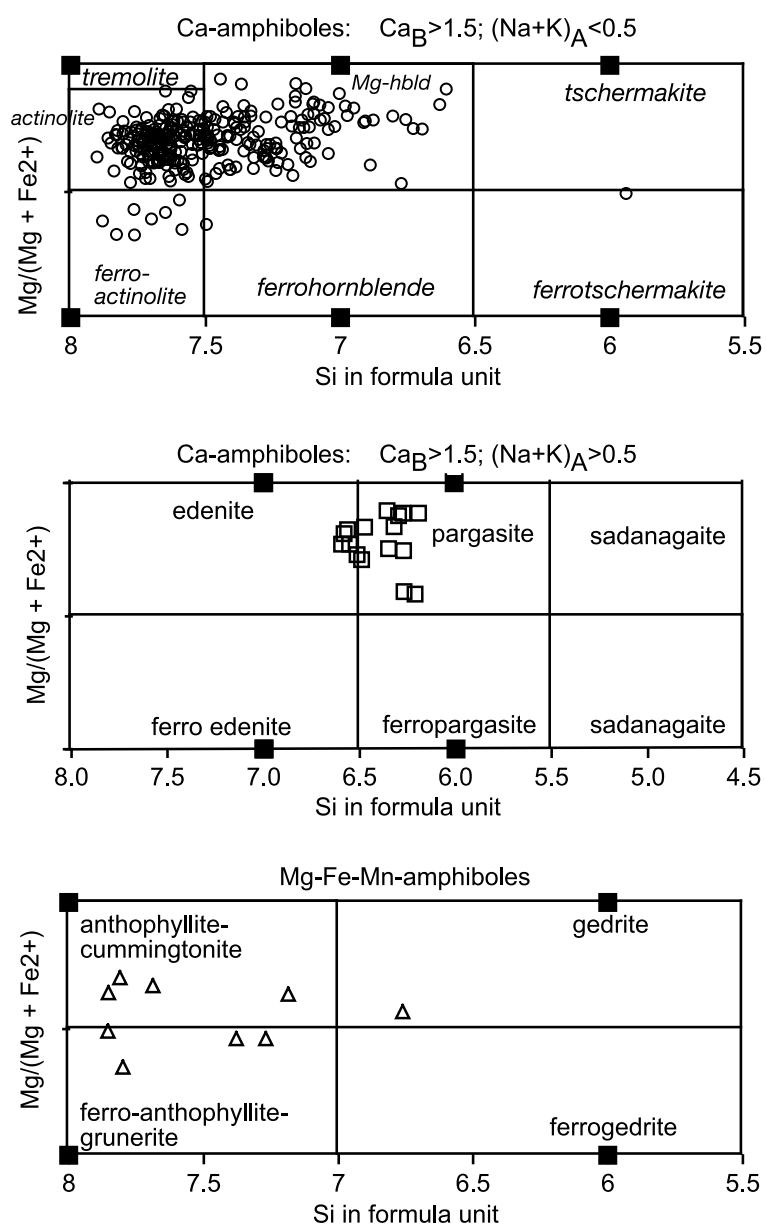

Figure 9. Compositions of amphiboles in Hole 1256D. Circles, calcic amphiboles; squares, pargasite-edenite; triangles, $\mathrm{Fe}-\mathrm{Mg}$ amphiboles.

\subsubsection{Sulfide Mineralization in Breccias, Dike Margins, and Veins}

[28] A prominent feature at 1027 mbsf, near the top of the transition zone, is the presence of a $\sim 3 \mathrm{~m}$ thick mineralized hyaloclastite breccia (Figures $7 \mathrm{~b}$ and 8f). Glass shards are replaced by chlorite, albiteoligoclase, K-feldspar, and titanite, and are cemented by abundant quartz and pyrite with lesser chalcopyrite, needles of actinolite, and local concentrations of sphalerite and anhydrite. Minor late calcite is also present in veins.

[29] Dike margins are commonly brecciated and mineralized, with the host rocks extensively replaced by chlorite, amphibole, titanite, albite and local K-feldspar (Figure 7c). The brecciated chilled margins are cut by veins of chlorite, amphibole, quartz, magnetite, and pyrite, common chalcopyrite and sphalerite, and local anhydrite. Magnetite is partly replaced by small amounts of hematite. Similar mineral assemblages are common in veins throughout the sheeted dikes above $1350 \mathrm{mbsf}$.

\subsubsection{Granoblastic Dikes and Dike Screens}

[30] Below $1348 \mathrm{mbsf}$, the dikes are variably recrystallized to microcrystalline, granular aggregates of secondary clinopyroxene, plagioclase, magnetite and ilmenite, \pm orthopyroxene, \pm quartz, and with late amphibole replacing pyroxenes. These rocks contain $0.5-1 \mathrm{~mm}$ completely recrystallized patches within variably recrystallized host rocks, and are referred to as the granoblastic dikes (Figure 8e) [Teagle and Expedition 309/312 Scientists, 2006; Koepke et al., 2008]. Rocks from the dike screens between and below the gabbro bodies exhibit alteration identical to that of the granoblastic dikes overlying the gabbros.

[31] Recrystallized plagioclase has compositions of $A n_{44}-A n_{65}$, within the range of igneous plagioclase (Figure 6). $\mathrm{MgO}$ contents are low, however, similar to secondary plagioclase (Figure 6). Compared to igneous augites, secondary clinopyroxenes are relatively $\mathrm{Ca}$-rich and range to diopside com-

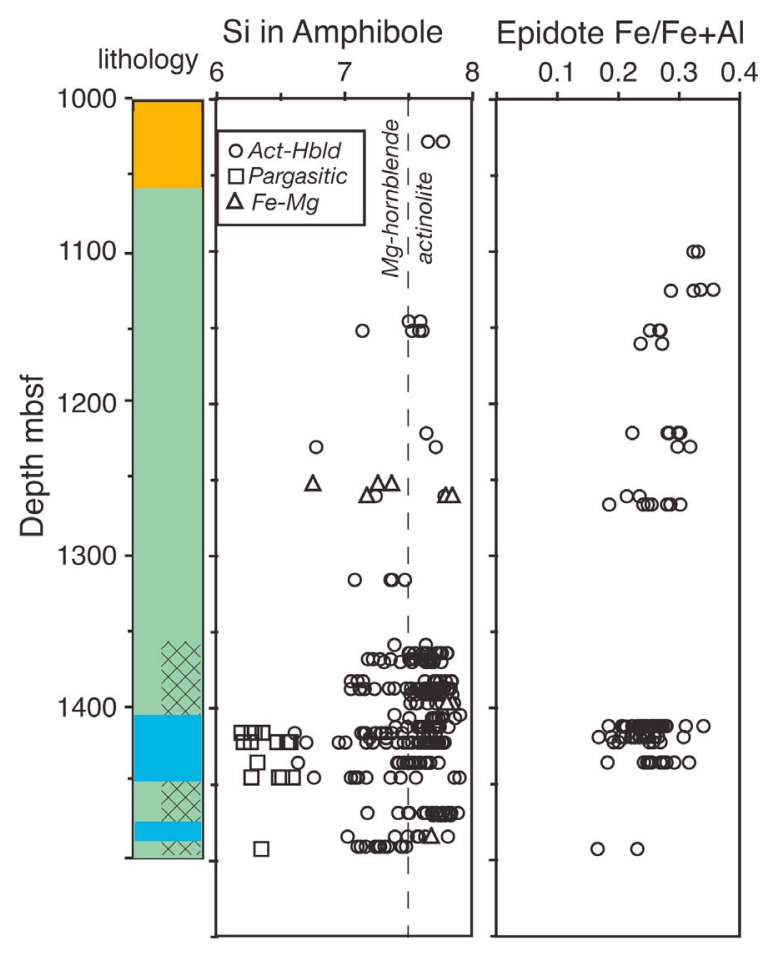

Figure 10. Amphibole and epidote formula compositions versus depth. Amphibole classification from Figure 9. Lithology as in Figure 2. 
positions; orthopyroxenes are hypersthene (Table 1 and Figure 5).

[32] Secondary clinopyroxene and orthopyroxene commonly contain blebs of secondary magnetite like those in amphibole replacing clinopyroxene in the overlying rocks. Clinopyroxene phenocrysts rarely have rims of secondary clinopyroxene with inclusions of magnetite, identical to the occurrence of amphibole + magnetite in the shallower dikes. These textures plus compositional data for phenocrysts and rims [Koepke et al., 2008] indicate derivation of secondary pyroxenes from igneous clinopyroxene that was previously hydrothermally altered to amphibole + magnetite. The patchiness of the granoblastic recrystallization is consistent with prior hydrothermal alteration influencing the intensity of granoblastic recrystallization, which varies even within a single thin section [Teagle and Expedition 309/312 Scientists, 2006].

[33] Two types of vein are present in the granoblastic dikes. The first consists of $\sim 1 \mathrm{~mm}$ wide felsic veins that contain subequal amounts of subhedral quartz and plagioclase, with minor coarse grained and fibrous interstitial amphiboles, plus trace FeTi oxides and needles of apatite. These veins are remarkably similar to tonalite veins that result from partial melting of hydrated dike rocks [Gillis and Coogan, 2002; Koepke et al., 2008; France et al., 2009]. In one case (at $1363.70 \mathrm{mbsf}$ ), actinolite occurs with oligoclase $\left(\mathrm{An}_{21-30}\right)$ in the vein, and actinolite replaces clinopyroxene and orthopyroxene in the granoblastic wallrock. In another case (at $1367.52 \mathrm{mbsf}$ ), actinolite and minor Mg-hornblende are present with andesine $\left(\mathrm{An}_{48}\right)$ in the vein, and $\mathrm{Mg}$-hornblende replaces wallrock pyroxenes.

[34] The second type of vein consists of $\sim 1 \mathrm{~mm}$ wide coarse $\mathrm{Mg}$-hornblende + actinolite veins having sharp to diffuse contacts with the host rock, and containing bands and patches of granular material. Some of these veins contain a few percent quartz, apatite, and/or sulfides (pyrite and chalcopyrite) with the amphibole. One Mg-hornblende + actinolite vein (at $1382.19 \mathrm{mbsf}$ ) contains up to $400 \mu \mathrm{m}$ grains of andesine $\left(\mathrm{An}_{35}\right)$, partly replaced by anorthite $\left(\mathrm{An}_{88}\right)$ in small patches. A vein at 1386.97 mbsf contains irregular patches, up to $\sim 1 \mathrm{~mm}$, of granular $\mathrm{Mg}-$ hornblende + anorthite $\left(\mathrm{An}_{92-98}\right)$ and local quartz, with anorthite partly replaced by albite. Included granoblastic material in the veins is variably replaced by actinolite and oligoclase. Pyroxenes in the wallrock surrounding these veins are variably replaced by $\mathrm{Mg}$-hornblende and actinolite, but $\mathrm{Fe}-\mathrm{Mg}$ amphibole also replaces granular orthopyroxene (e.g., at 1397 mbsf; Figure 10). Orthopyroxenes in the dike screens are also locally partly replaced by smectite, talc, and chlorite-smectite.

[35] Mineral parageneses indicate a series of retrograde reactions, from contact metamorphism and formation of felsic veins, to $\mathrm{Mg}$-hornblende and local anorthite in veins and host rocks, to actinolite and oligoclase in veins and rocks, to late albite replacing earlier more calcic plagioclase, and finally smectite and chlorite-smectite replacing orthopyroxene.

[36] The lowermost dike recovered in the hole exhibits alteration similar to that in the upper dike complex, with partial alteration to actinolite, albite, chlorite, and titanite.

\subsubsection{Plutonic Rocks}

[37] The plutonic rocks are variably altered, with the intensity of replacement related to texture of the rock and proximity to intrusive contacts and veins. Regions of gabbro with large ophitic clinopyroxenes enclosing plagioclase are less altered than irregular coarser grained zones between, giving the rocks a patchy appearance in hand specimen (Figure 7d).

[38] Clinopyroxene in the plutonic rocks is extensively to totally replaced by amphibole + dusty to granular magnetite $(\sim 1-40 \mu \mathrm{m})$ (Figure 11). Amphibole compositions typically range from $\mathrm{Mg}$ hornblende to actinolite and local ferroactinolite, but clinopyroxene can also contain small patches of brown pargasite, most likely of late magmatic origin [Banerjee and Gillis, 2001; Coogan et al., 2001]. Fe-Mg amphibole is present locally, for example replacing orthopyroxene at $1490 \mathrm{mbsf}$ and with actinolite replacing pyroxene at $1484 \mathrm{mbsf}$ (Figure 10). Plagioclase is generally only slightly altered to albite-oligoclase $\left(\mathrm{An}_{1-30}\right)$, and to small amounts of amphibole, chlorite, epidote, prehnite and laumontite (Figure 11). Olivine, where present, is variably altered to smectite-chlorite, chlorite, talc, calcite, magnetite, pargasite, $\mathrm{Mg}$ hornblende, and rare actinolite (Figure 11). These minerals are commonly zoned, from an inner core of fresh olivine with veins of magnetite, outward to smectitechlorite or chlorite \pm calcite, to colorless $\mathrm{Mg}$ hornblende + magnetite, to pale green pargasite.

[39] Oxide minerals consist of titanomagnetite and ilmenite, either as subgrains within individual grains or as oxidation/exsolution lamellae of ilmenite 

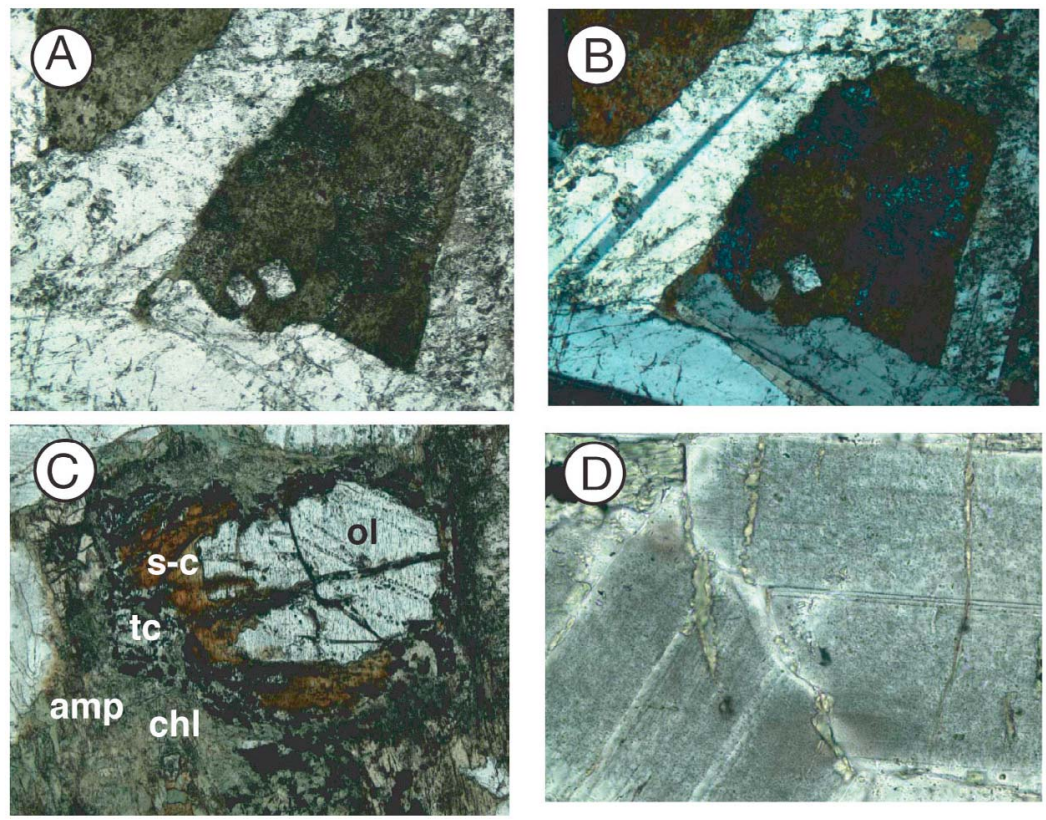

Figure 11. Thin section photomicrographs of Gabbro alteration. (a) Clinopyroxene altered to hornblende. Plagioclase is partly altered to secondary plagioclase ( $\mathrm{An}_{9-42}$; sample $312-1256 \mathrm{D}-223 \mathrm{R}-1,42-45 \mathrm{~cm} ; 1449.72 \mathrm{mbsf}$ ) (plane polarized light; field of view $(\mathrm{FOV})=4.5 \mathrm{~mm}$ ). (b) Same as Figure 11a but with crossed polars. (c) Olivine partly replaced by smectite-chlorite (s-c) + magnetite + minor talc (tc), with an outer zone of chlorite (chl) and amphibole (amp) (sample 312-1256D-223R-1, 42-43 cm; 1449.72 mbsf) (plane-polarized light; field of view (FOV) = $2.25 \mathrm{~mm}$ ). (d) Plagioclase riddled with tiny inclusions and cut by veinlets of amphibole and albite (sample 312$1256 \mathrm{D}-232 \mathrm{R}-2,98-100 \mathrm{~cm} ; 1494.96 \mathrm{mbsf}$ ) (plane-polarized light; FOV = $0.6 \mathrm{~mm}$ ).

within magnetite, and are variably altered to titanite. Igneous apatite is present in gabbros and felsic veins, but apatite also occurs in the upper gabbro as up to $1 \mathrm{~mm}$ irregular porous crystals in altered plagioclase and with hornblende replacing pyroxene. The mode of occurrence of this apatite suggests a possible hydrothermal origin, but the high $\mathrm{F}$ contents and $\mathrm{F} /(\mathrm{F}+\mathrm{Cl})(0.74-2.74$ wt $\%$ and $\sim 0.5$, respectively) favor a magmatic origin.

[40] Hydrothermal effects are generally similar in the upper and lower gabbro bodies, but the lower gabbro contains orthopyroxene, which is variably replaced by $\mathrm{Mg}$ hornblende, talc, and chloritesmectite. Granoblastic assemblages are present in stoped dike fragments (up to $10 \mathrm{~cm}$ ) at the margins of the lower gabbro body. Granoblastic textures elsewhere within the lower gabbro reflect assimilation of stoped rocks [France et al., 2009].

[41] The plutonic rocks contain an average of 10 veins $/ \mathrm{m}$ of recovered core. The earliest generation consists of linear zones of amphibole replacing pyroxenes, with 1-2 mm wide amphibole-rich alteration halos. These are cut by $0.5-1 \mathrm{~mm}$ wide veins of amphibole filling open fractures, in some cases also containing granular plagioclase $\left(\mathrm{An}_{17-40}\right)$. Vein amphibole compositions range from $\mathrm{Mg}$ hornblende to pargasite and edenite. These early veins are cut by veins of actinolite, chlorite, quartz, epidote, and prehnite, bordered by $2-5 \mathrm{~mm}$ alteration halos containing actinolite, chlorite, albite, titanite, and local FeMg amphibole.

\subsection{Fluid Inclusions}

[42] Most fluid inclusions in quartz in the dikes and gabbros have salinities of $0.5-12.2$ equivalent wt $\% \mathrm{NaCl}$, and homogenization temperatures of $213^{\circ} \mathrm{C}-446^{\circ} \mathrm{C}$. Assuming $2.5-3.0 \mathrm{~km}$ water depth and up to $1 \mathrm{~km}$ subseafloor sample depths gives hydrostatic pressures of $\sim 350-400$ bars. Applying these pressure corrections to the homogenization temperatures gives trapping temperatures of $269^{\circ} \mathrm{C}-$ $469^{\circ} \mathrm{C}$ (Table 2). Average values of trapping temperatures for individual samples are $355^{\circ} \mathrm{C}-425^{\circ} \mathrm{C}$, and average salinities are 2.2-9.2 wt $\% \mathrm{NaCl}$ (Figure 12 and Table 2). Samples from the sheeted dikes tend to have lower average salinities than those from the granoblastic dikes and upper gabbro ( $<6$ versus $>7$ wt $\% \mathrm{NaCl}$, respectively; Figure 12). Otherwise, there are no consistent differences 
Table 2. Hole 1256D Fluid Inclusion Data Summary ${ }^{\mathrm{a}}$

\begin{tabular}{|c|c|c|c|c|c|c|c|c|c|c|c|}
\hline $\begin{array}{l}\text { Core Section, } \\
\mathrm{cm} \text { Interval }\end{array}$ & $\begin{array}{l}\text { Depth } \\
\text { (mbsf) }\end{array}$ & $\begin{array}{l}\text { Rock } \\
\text { Type }\end{array}$ & Occ & $\mathrm{n}$ & $\begin{array}{l}\text { Salinity } \\
\text { Range }\end{array}$ & $\begin{array}{c}\text { Salinity } \\
\text { Mean }\end{array}$ & $1 \mathrm{~s}$ & $\begin{array}{l}\text { Pressure } \\
\text { (bars) }\end{array}$ & Tt Range & Tt Mean & $1 \mathrm{~s}$ \\
\hline $173 \mathrm{R} 1,107-110$ & 1261.67 & dike & Qz vein & 19 & $1.3-10.1$ & 5.7 & 2.5 & 350 & $269-422$ & 386 & 34 \\
\hline 176R1, 41-44 & 1276.51 & dike & Qz vug & 23 & $2.0-7.3$ & 5.6 & 1.1 & 350 & $250-431$ & 355 & 57 \\
\hline 176R1, 107-109 & 1277.17 & dike & Qz vein & 15 & $0.5-6.8$ & 2.2 & 1.9 & 350 & $352-456$ & 425 & 25 \\
\hline 194R1, 45-47 & 1358.35 & $\begin{array}{l}\mathrm{Gb} \\
\text { dike }\end{array}$ & $\begin{array}{l}\text { tonalite } \\
\text { vein }\end{array}$ & $\begin{array}{l}16 \\
17\end{array}$ & $\begin{array}{c}2.8-11.7 \\
47.2 \text { to }>50\end{array}$ & 7.6 & 3.1 & 390 & $\begin{array}{c}312-436 \\
398 \text { to }>450\end{array}$ & $\begin{array}{c}369 \\
>420\end{array}$ & 34 \\
\hline 212R1, 29-31 & 1404.39 & $\begin{array}{l}\text { felsic } \\
\text { vein }\end{array}$ & $\begin{array}{l}\text { ground } \\
\text { mass }\end{array}$ & $\begin{array}{c}11 \\
6\end{array}$ & $\begin{array}{c}5.8-11.2 \\
>50\end{array}$ & 9.2 & 1.8 & 400 & $\begin{array}{c}275-469 \\
>450\end{array}$ & 394 & 60 \\
\hline 214R1, 94-95 & 1411.84 & gabbro & $\begin{array}{l}\text { ground } \\
\text { mass }\end{array}$ & $\begin{array}{l}4 \\
8\end{array}$ & $\begin{array}{c}6.34-9.0 \\
>50\end{array}$ & 7.6 & 1.1 & 400 & $\begin{array}{c}346-383 \\
>400\end{array}$ & 375 & 19 \\
\hline 219R1, 61-62 & 1430.61 & gabbro & Qz vein & 4 & $3.7-12.2$ & 7.0 & 3.9 & 410 & $332-427$ & 372 & 43 \\
\hline 222R1, 144-149 & 1446.04 & gabbro & Qz vein & $\begin{array}{c}10 \\
2\end{array}$ & $\begin{array}{c}5.8-11.2 \\
>50\end{array}$ & 7.0 & 1.4 & 410 & $\begin{array}{c}275-469 \\
>450\end{array}$ & 386 & 42 \\
\hline
\end{tabular}

${ }^{a}$ All inclusions contained within quartz. Salinity in wt \% NaCl equivalent; $\mathrm{Tt}$ is trapping temperature (corrected for assumed hydrostatic pressure, see section 3.2). N, number of analyses; $1 \mathrm{~s}, 1$ sigma. Inclusions fall into two groups, lower salinity and hypersaline. Mean values given for lowersalinity group, and minimum values given for hypersaline group (see section 3.2 for details). Data given in auxiliary material. Gb, granoblastic texture; Occ, occurrence.

between veins and vugs in the dikes, or between quartz veins and groundmass in the gabbros. Data for the tonalite vein are similar to those for quartz veins, whereas the plagiogranite vein has the highest average salinity (9.2 wt \%: Table 2$)$. Eight percent of all fluid inclusions were tentatively identified as secondary, but there is no consistent difference in homogenization temperature or salinity between primary and possible secondary inclusions.

[43] Some inclusions from felsic veins in the granoblastic dikes and from vein and groundmass quartz in the upper gabbro contain daughter halite crystals and did not homogenize at temperatures of $450^{\circ} \mathrm{C}$, approximately the maximum usable temperature with the heating-freezing stage. Assuming a simple $\mathrm{NaCl}-\mathrm{H}_{2} \mathrm{O}$ system, this implies a salinity of greater than about $50 \%$ for these inclusions, which are all identified as primary inclusions (Table 2).

\subsection{Oxygen Isotopes}

[44] Oxygen isotope analyses of vein minerals are given in Table 3. In the volcanic section, the $\delta^{18} \mathrm{O}$ values of secondary minerals generally decrease with depth. Smectite and chlorite-smectite in the lavas have $\delta^{18} \mathrm{O}$ values of $6.8 \%{ }^{-}-17.8 \%$, and two celadonites have values of $13.2 \%$ and $17.2 \%$. Quartz and chalcedony in the volcanic section have

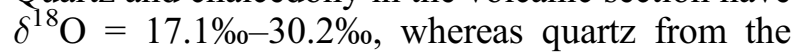
transition zone, dikes, and plutonic section has lower $\delta^{18} \mathrm{O}$ values of 5.5\% $-9.4 \%$. Quartz from the tonalite vein in the granoblastic dikes has $\delta^{18} \mathrm{O}=$ $7.0 \%$, within the range of vein quartz. Two epidote separates from alteration patches in a dike and a gabbro have $\delta^{18} \mathrm{O}$ values of $1.4 \%$ and $0.5 \%$, respectively. Fourteen anhydrites have $\delta^{18} \mathrm{O}$ values in the range $9.0 \%{ }^{-}-17.7 \%$, whereas two others have more extreme values of $2.2 \%$ and $29.0 \%$.

\section{Discussion}

[45] The hydrothermal system and alteration processes at Site 1256 are discussed below in terms of depth, lithology, and time. We start with hightemperature reactions at the bottom of the section, documenting changes in the system through time,

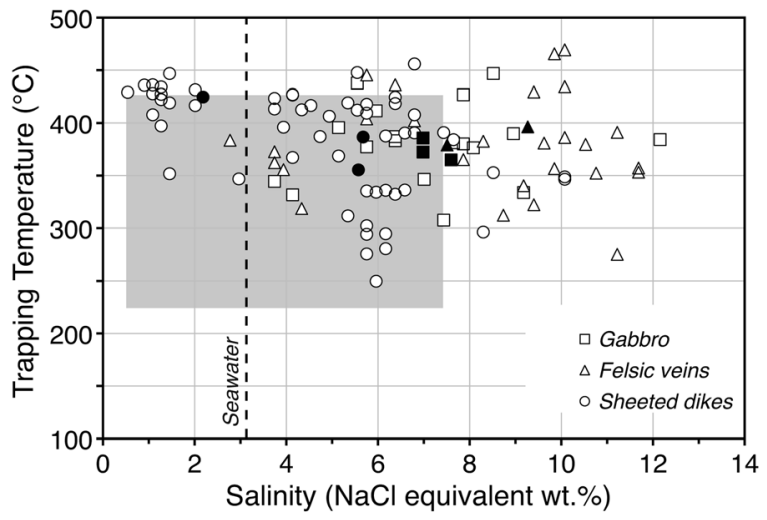

Figure 12. Trapping temperatures and salinities for fluid inclusions in quartz (sample average values in solid symbols). Most inclusions have trapping temperatures and salinities similar to seafloor vent fluids (shaded box [Von Damm, 1995]) and are explained by supercritical phase separation processes (see section 4.4). Hypersaline inclusions ( 50 wt $\% \mathrm{NaCl}$, see Table 2 ) did not homogenize at the maximum temperature measured $\left(450^{\circ} \mathrm{C}\right)$ and plot off scale at top right. Dashed line is seawater salinity shown for comparison. Solid symbols are sample averages. 
Table 3. Hole 1256D Oxygen Isotope Data, Equilibrium Temperatures, and Fluids ${ }^{\mathrm{a}}$

\begin{tabular}{|c|c|c|c|c|c|c|c|c|c|}
\hline $\begin{array}{c}\text { Core } \\
\text { Section }\end{array}$ & $\begin{array}{c}\text { Centimeter } \\
\text { Interval }\end{array}$ & $\begin{array}{l}\text { Depth } \\
\text { (mbsf) }\end{array}$ & Mineral & Occurrence & $\delta^{18} \mathrm{O}(\%)$ & $\begin{array}{l}\mathrm{T}^{\mathrm{b}} \\
\left({ }^{\circ} \mathrm{C}\right)\end{array}$ & $\begin{array}{c}\text { Fluid } \\
\text { Inclusion } \\
\mathrm{T}\left({ }^{\circ} \mathrm{C}\right)\end{array}$ & $\begin{array}{l}\text { Fluid } \\
\delta^{18} \mathrm{O}\end{array}$ & $\begin{array}{l}\mathrm{T}^{\mathrm{c}} \\
\left({ }^{\circ} \mathrm{C}\right)\end{array}$ \\
\hline $5 \mathrm{R} 1$ & $17-32$ & 252.57 & saponite & vein & 16.2 & 60 & & & \\
\hline $6 \mathrm{R} 4$ & $53-56$ & 261.6 & chalcedony & vein & 30.2 & 49 & & & \\
\hline 8R1 & $47-48$ & 313.77 & saponite & vein & 16.7 & 56 & & & \\
\hline $8 \mathrm{R} 6$ & $0-3$ & 319.11 & quartz & vein & 24.0 & 81 & & & \\
\hline $12 \mathrm{R} 7$ & $101-104$ & 350.12 & quartz & vein & 28.1 & 58 & & & \\
\hline $14 \mathrm{R} 1$ & $23-28$ & 359.73 & saponite & vein & 17.8 & 48 & & & \\
\hline 18R2 & $136-138$ & 380.62 & saponite & vein & 17.3 & 52 & & & \\
\hline 22R2 & $67-70$ & 407.9 & quartz & vein & 27.7 & 60 & & & \\
\hline $26 R 3$ & $90-93$ & 441.82 & quartz & vein & 25.0 & 75 & & & \\
\hline 27R2 & $105-108$ & 447.89 & celadonite & vein & 17.2 & 70 & & & \\
\hline $35 \mathrm{R} 2$ & $108-111$ & 491.33 & quartz & vein & 26.4 & 67 & & & \\
\hline $35 \mathrm{R} 2$ & $108-111$ & 491.33 & saponite & vein & 14.3 & 75 & & & \\
\hline $43 \mathrm{R} 2$ & $13-16$ & 535.53 & quartz & vein & 22.6 & 90 & & & \\
\hline 47R2 & $141-144$ & 573.91 & saponite & vein & 13.9 & 79 & & & \\
\hline $53 R 2$ & $13-21$ & 611.4 & quartz & vein & 21.3 & 99 & & & \\
\hline $55 \mathrm{R} 2$ & $118-122$ & 628.58 & chalcedony & vein & 23.9 & 81 & & & \\
\hline $57 \mathrm{R} 2$ & $70-74$ & 647.55 & quartz & vein & 20.1 & 108 & & & \\
\hline $57 \mathrm{R} 2$ & $70-74$ & 647.55 & chalcedony & vein & 22.1 & 93 & & & \\
\hline $57 \mathrm{R} 2$ & $75-76$ & 647.6 & saponite & vein & 15.4 & 66 & & & \\
\hline $60 \mathrm{R} 1$ & $35-38$ & 668.95 & saponite & vein & 8.9 & 135 & & & \\
\hline 68R1 & $112-113$ & 720.62 & quartz & vein & 21.2 & 99 & & & \\
\hline 70R2 & $8-12$ & 730.24 & celadonite & vein & 13.2 & 100 & & & \\
\hline $72 \mathrm{R} 1$ & $140-149$ & 739.3 & quartz & vein & 24.3 & 79 & & & \\
\hline $81 \mathrm{R}-1$ & $58-60$ & 789.4 & anhydrite & haloclastite & 14.5 & 136 & & & \\
\hline 81R2 & 88 & 789.68 & quartz & vein & 17.1 & 133 & & & \\
\hline $85 \mathrm{R} 2$ & $118-123$ & 814 & saponite & vein & 11.9 & 98 & & & \\
\hline $85 \mathrm{R} 6$ & 26 & 818.51 & quartz & vein & 25.6 & 72 & & & \\
\hline 99R1 & 82 & 908.22 & quartz & vein & 22.1 & 93 & & & \\
\hline 100R2 & $10-14$ & 912.14 & saponite & vein & 9.6 & 125 & & & \\
\hline 108R1 & 119 & 959.99 & quartz & vein & 22.7 & 89 & & & \\
\hline $114 \mathrm{R}-1$ & $113-116$ & 989.93 & anhydrite & vein w. zeolite & 17.7 & 105 & & & \\
\hline 117R1 & $12-14$ & 1003.32 & saponite & vein & 5.8 & 185 & & & \\
\hline $118 \mathrm{R}-1$ & $11-13$ & 1008.1 & anhydrite & alt. patch & 14.1 & 140 & & & \\
\hline $122 \mathrm{R}-2$ & $71-73$ & 1029.51 & anhydrite & breccia, glass, ab,py & 14.9 & 131 & & & \\
\hline $122 \mathrm{R}-2$ & $73-78$ & 1029.54 & anhydrite & breccia, glass, ab,py & 14.5 & 136 & & & \\
\hline $123 \mathrm{R}-1$ & $31-34$ & 1032.41 & anhydrite & vein & 13.1 & & & & \\
\hline $128 \mathrm{R}-1$ & $47-51$ & 1056.57 & anhydrite & hyalo br: sap, zeol, sulf & 10.9 & 180 & & & \\
\hline $130 \mathrm{R}-1$ & $85-89$ & 1066.55 & anhydrite & $a n h+$ sap + qz vein & 11.3 & 174 & & & \\
\hline $135 \mathrm{R}-1$ & $104-108$ & 1090.74 & anhydrite & vug w. qz + py & 16.3 & 117 & & & \\
\hline 137R1 & 4 & 1099.34 & quartz & vein & 7.8 & & & & 356 \\
\hline $140 \mathrm{R}-1$ & $29-33$ & 1113.99 & anhydrite & dike margin br: chl $+\mathrm{cp}$ & 2.2 & 408 & & & \\
\hline $145 \mathrm{R}-2$ & $83-89$ & 1139.83 & anhydrite & chl + py vein (late anh) & 9.0 & 211 & & & \\
\hline $151 \mathrm{R}-1$ & $111-114$ & 1166.41 & anhydrite & chl + py vein & 29.0 & 36 & & & \\
\hline 151R1 & 111 & 1166.41 & quartz & vein & 9.0 & & & & 318 \\
\hline $156 \mathrm{R}-2$ & $86-91$ & 1191.69 & anhydrite & chl + qz + py vn (late anh) & 11.0 & 179 & & & \\
\hline $157 \mathrm{R}-1$ & $142-146$ & 1195.62 & anhydrite & vein 1 & 9.7 & 199 & & & \\
\hline 170R-1 & $66-70$ & 1252.46 & anhydrite & chl + qz vein (late anh) & 9.8 & 197 & & & \\
\hline 173R1 & $88-94$ & 1261.48 & quartz & vein & 7.1 & & $386^{\mathrm{d}}$ & 1.6 & 382 \\
\hline 174R1 & $91-98$ & 1266.31 & quartz & patch & 6.8 & $354^{\mathrm{e}}$ & & 0.4 & \\
\hline 174R1 & $91-98$ & 1266.31 & epidote & patch & 1.4 & & & & \\
\hline 191R1 & $6-11$ & 1343.56 & quartz & vein & 5.5 & & & & 454 \\
\hline 194R1 & $9-14$ & 1357.99 & quartz & tonalite vein & 7.0 & & $369^{f}$ & 1.0 & 386 \\
\hline 202R1 & $5-15$ & 1372.85 & quartz & vein & 7.8 & & & & 358 \\
\hline 219R1 & $61-65$ & 1430.61 & quartz & vein & 9.4 & & $372^{\mathrm{g}}$ & 3.5 & 308 \\
\hline 222R1 & $67-71$ & 1445.27 & quartz & vein & 6.9 & & $386^{\mathrm{h}}$ & 1.4 & 390 \\
\hline 225R1 & $8-9$ & 1458.98 & quartz & vein & 5.9 & & & & 434 \\
\hline 227R1 & $92-96$ & 1469.42 & quartz & patch & 9.0 & $226^{\mathrm{e}}$ & & -2.8 & \\
\hline 227R1 & $92-96$ & 1469.42 & epidote & patch & 0.5 & & & & \\
\hline
\end{tabular}


and work upward to lower-temperature processes in the lavas.

\subsection{Early Hydrothermal Alteration and Contact Metamorphism in the Granoblastic Dikes and Plutonic Section}

[46] Petrographic and lithologic relationships show that the granoblastic dikes and the dike screens were initially hydrothermally altered, then underwent a stage of high-temperature contact metamorphism. The variability in high-temperature recrystallization, plus the presence of magnetite grains within secondary pyroxenes, identical to the occurrence of magnetite with amphibole replacing pyroxene in the upper dikes, are textural evidence for an early stage of hydrothermal alteration. Losses of $\mathrm{Cu}$ and $\mathrm{Zn}$ from the granoblastic dike are also consistent with an early period of hydrothermal alteration of these rocks (see section 4.5).

[47] The mineral assemblages of the granoblastic dikes and dike screen provide a record of the contact metamorphism. Applying the two-pyroxene thermometer of Brey and Kohler [1990] to pyroxene data for 8 samples of granoblastic dikes gives temperatures of $800^{\circ} \mathrm{C}-924^{\circ} \mathrm{C}$, with no clear depth trend (Table 1). Temperature estimates from different areas within individual thin sections generally vary by less than $50^{\circ} \mathrm{C}$, but in one sample at $1404 \mathrm{mbsf}$ calculated temperatures vary by $100^{\circ} \mathrm{C}$ (Table 1$)$. Koepke et al. [2008] obtained higher temperatures of $935^{\circ} \mathrm{C}-1045^{\circ} \mathrm{C}$ for the granoblastic dikes using the QUILF two-pyroxene thermometer of Andersen et al. [1993]. Comparison of temperatures of various published experiments with those calculated using two-pyroxene thermometers, however, shows that the Brey and Kohler [1990] thermometer gives smaller average deviations from the experimental temperatures than does the QUILF thermometer, $70^{\circ} \mathrm{C}$ versus $113^{\circ} \mathrm{C}$, respectively [Putirka, 2008; Blundy and Cashman, 2008]. Recalculation of the pyroxene data from Koepke et al. [2008] using the Brey and Kohler thermometer for comparison gives temperatures of $\sim 850^{\circ} \mathrm{C}-950^{\circ} \mathrm{C}$, similar to results in Table 1.

[48] Data for the dike screen between the two gabbro bodies and for the lower gabbro unit indicate that these rocks experienced peak metamorphic temperatures similar to those in the granoblastic dikes. Two-pyroxene thermometry yields a temperature estimate of $861^{\circ} \mathrm{C}$ for one sample from the upper dike screen, and $755^{\circ} \mathrm{C}-900^{\circ} \mathrm{C}$ for two samples of the lower gabbro (Table 1).

[49] Temperatures of contact metamorphism are consistent with those for hydrous partial melting [Gillis and Coogan, 2002; Koepke et al., 2008], and felsic veins in the granoblastic dikes are suggested to result from partial melting of previously hydrated sheeted dikes [France et al., 2009]. The tonalite veins in the granoblastic dikes are probably the result of this process. The presence of local andesine and apatite in the amphibole-rich veins in the granoblastic dikes suggests that these veins may also have a magmatic component.

[50] The two gabbro sills penetrated by the drill hole have insufficient thermal mass to produce a 60 to $90 \mathrm{~m}$ contact metamorphic halo [Koepke et al., 2008; Coggan et al., 2008], suggesting a larger intrusion below. Alternatively, there may be significant lateral relief on the sheeted dike gabbro boundary at Site 1256 . The most strongly recrystallized diabases are not at the boundary with the underlying gabbro sills, suggesting that other gabbroic bodies may be present at slightly shallower levels nearby [Teagle and Expedition 309/ 312 Scientists, 2006].

\subsection{Post-Contact Metamorphism Hydrothermal Alteration of the Granoblastic Dikes and Plutonic Section}

[51] The earliest hydrous alteration phases in the granoblastic dikes and plutonic section are amphiboles. We did not use plagioclase-amphibole thermometry for our samples because adjacent

\footnotetext{
Notes to Table 3:

${ }^{\text {a } A b b r e v i a t i o n s ~ a r e ~ a s ~ f o l l o w s: ~ a n h, ~ a n h y d r i t e ; ~ s a p, ~ s a p o n i t e ; ~ q z, ~ q u a r t z ; ~ p y, ~ p y r i t e ; ~ b r, ~ b r e c c i a . ~ S e e ~ s e c t i o n ~} 4.4$ for details and discussion.

${ }^{\mathrm{b}}$ Temperatures in the volcanic section $(<1004 \mathrm{mbsf})$ assume equilibrium with seawater (0\%) for saponite [Buatier et al., 1995], celadonite [Savin and Lee, 1988] and quartz $\left(<200^{\circ} \mathrm{C}\right.$ [Zheng, 1993]).

${ }^{\mathrm{c}}$ Temperatures for quartz in the transition zone, dikes, and gabbros (below $1004 \mathrm{mbsf}, \mathrm{T}>200^{\circ} \mathrm{C}$ ) based on fluid inclusions and assuming hydrothermal fluid $\mathrm{d} 18 \mathrm{O}=1.5 \%$ using quartz-water fractionation from Sharp and Kirschner [1994]. Temperatures for anhydrite assume equilibrium between sulfate and seawater [Chiba et al., 1981].

${ }^{\mathrm{d} F r o m ~ 173 R 1, ~ 107-110 . ~}$

eUsing quartz-epidote fractionation from [Matthews and Schliestedt, 1984], and quartz-water fractionation from Sharp and Kirschner [1994].

${ }^{\mathrm{f}}$ From 194R1, 45-47.

${ }^{\mathrm{g}}$ From 219R1, 61-62.

${ }^{\mathrm{h}}$ From 222R1, 144-149.
} 


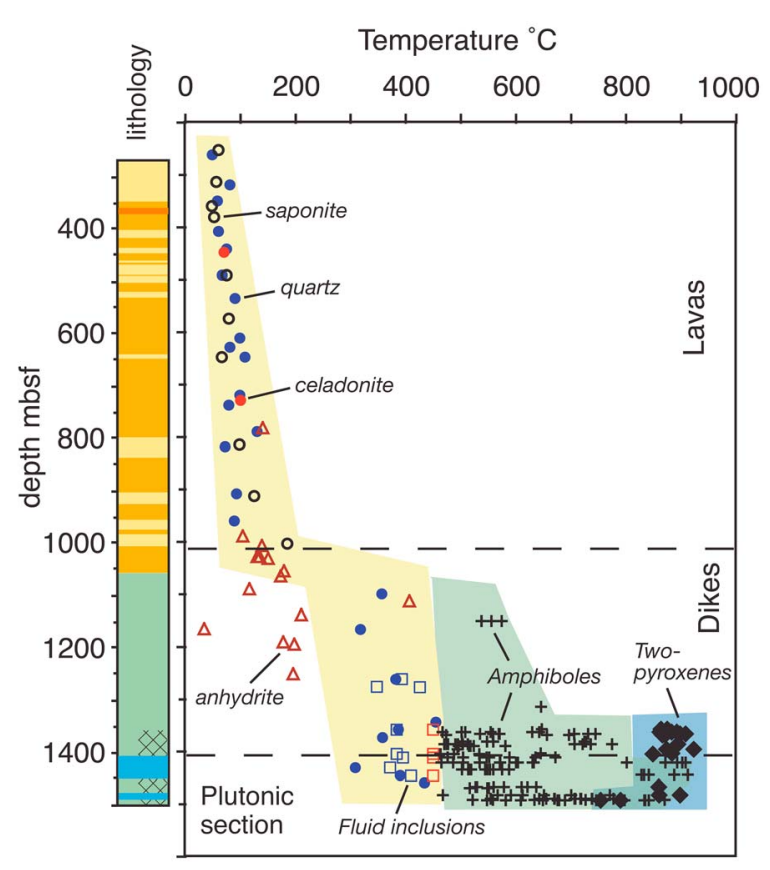

Figure 13. Temperatures estimated from various mineral thermometers in Hole 1256D. Note step in thermal gradient from low temperatures in the lavas to hydrothermal alteration in the sheeted dikes. Amphibole and two-pyroxene thermometry (solid diamonds) record stepwise increase to near-magmatic temperatures in the granoblastic dikes and plutonic section. Anhydrites (open triangles) record either nonequilibrium temperatures of precipitation or precipitation during collapse and cooling of the system. Temperatures estimated from oxygen isotopes (saponite, open circles; celadonite, solid red circles; quartz, solid blue circles; anhydrite, open triangles), fluid inclusions in quartz (open squares; hypersaline inclusions plotted in red at minimum temperature of $450^{\circ} \mathrm{C}$ ), Ti contents of amphiboles (crosses), and twopyroxene thermometry (solid diamonds). Lithology as in Figure 2.

plagioclase and amphibole were not always analyzed, and because textural evidence for equilibrium between these phases is commonly not clear. Compositions of plagioclase in the granoblastic dikes may reflect the contact metamorphism stage, with amphibole forming later during hydration of the granoblastic assemblages. Koepke et al. [2008] used the plagioclaseamphibole thermometer of Holland and Blundy [1994] for what they termed later "wet" granoblastic metamorphism of these rocks, and obtained temperatures of $708^{\circ} \mathrm{C}-854^{\circ} \mathrm{C}$.

[52] Ernst and Liu [1998] show that $\mathrm{TiO}_{2}$ and $\mathrm{Al}_{2} \mathrm{O}_{3}$ contents of calcic amphibole formed from midocean ridge basalt protoliths increase with temper- ature, providing a semiquantitative thermometer. Application of this semiquantitative amphibole thermometer to Hole $1256 \mathrm{D}$ analyses gives temperature estimates of $464^{\circ} \mathrm{C}-913^{\circ} \mathrm{C}$ (Figure 13). Equilibrium was at best attained locally in these samples during amphibole formation, and uncertainties in temperatures at low $\mathrm{TiO}_{2}$ contents $(<0.5 \mathrm{wt} \%)$ from Ernst and Liu's [1998] correlations are high, but uncertainties of $\pm 100^{\circ} \mathrm{C}$ for these estimates are probably reasonable. The highest temperatures, $829^{\circ} \mathrm{C}-913^{\circ} \mathrm{C}$, are for pargasite-edenite in the upper gabbro unit, where these amphiboles occur in olivine reaction coronas, replacing clinopyroxene, and in a vein with $\mathrm{Mg}$-hornblende and actinolite. Some of these hightemperature amphiboles are most likely late magmatic in origin. Temperatures estimated for other amphiboles in the gabbro bodies vary from $840^{\circ} \mathrm{C}$ down to $480^{\circ} \mathrm{C}$.

[53] The highest temperatures estimated for amphibole in the granoblastic dikes $\left(700^{\circ} \mathrm{C}-776^{\circ} \mathrm{C}\right)$ are for coarse amphibole veins and for wallrock associated with these veins (at 1387.03, 1382.19, and $1367.52 \mathrm{mbsf}$ ). Other amphibole temperatures for these rocks range from $650^{\circ} \mathrm{C}$ to $460^{\circ} \mathrm{C}$. Using the same semiquantitative thermometer, Koepke et al. [2008] obtained temperatures of $650^{\circ} \mathrm{C}-747^{\circ} \mathrm{C}$ for amphibole formation in the granoblastic dikes. Fluid inclusion and oxygen isotope data, discussed below, along with the mineralogy indicate that hydrothermal alteration continued throughout the cooling of the granoblastic dikes and plutonic section. Actinolitic amphiboles may have continued to form at temperatures down to $\sim 300^{\circ} \mathrm{C}$ [Bird et al., 1984].

\subsection{Early Alteration of the Sheeted Dikes and Transition Zone}

[54] Petrographic relationships indicate that clinopyroxene, amphibole (Mg-hornblende to actinolite), chlorite, albite-oligoclase, titanite, \pm pyrite formed relatively early in veins and bulk rocks throughout the transition zone and sheeted dikes. Application of the semiquantitative amphibole $\mathrm{Ti}$ thermometer [Ernst and Liu, 1998] to amphiboles in dikes gives temperature estimates as high as $540^{\circ} \mathrm{C}-$ $650^{\circ} \mathrm{C}$ (Figure 13). Local secondary clinopyroxenes in veins formed at comparable temperatures of $\sim 400^{\circ} \mathrm{C}-800^{\circ} \mathrm{C}$, based on the one-atmosphere solvus of Lindsley [1983] (Figure 5). Based on comparison with active geothermal areas, however, actinolite, chlorite and the other phases probably continued to form at lower temperatures, down to $\sim 300^{\circ} \mathrm{C}$ [Bird et al., 1984]. 


\subsection{Formation of Quartz and Associated Minerals in the Sheeted Dikes and Plutonic Section}

[55] Veins of quartz with other phases (chlorite, epidote, pyrite, chalcopyrite, magnetite, and local sphalerite) are common and overprint early hydrothermal alteration. Fluid inclusion and oxygen isotope data for quartz and epidote provide constraints on the quartz-forming hydrothermal fluids.

[56] Fluid inclusions in quartz veins and vugs are mainly relatively low salinity, having individual sample averages of $2.2-7.0 \mathrm{wt} \% \mathrm{NaCl}$ (Table 2). These inclusions have salinities and trapping temperatures similar to those of hydrothermal vent fluids at mid-ocean ridges (Figure 12) [Butterfield et al., 1994; Von Damm, 1995], but range to higher salinities. The variable salinities of the vent fluids result from processes related to supercritical phase separation. The critical point of seawater is $407^{\circ} \mathrm{C}$ and 298 bars [Bischoff and Rosenbauer, 1985]. At higher pressure and temperature, decompression or heating can lead to supercritical phase separation and formation of a lower-salinity vapor-like phase plus a high-salinity brine phase [Bischoff and Rosenbauer, 1985]. Separation and recombination of these phases in variable proportions in the subsurface results in the observed salinity variations of vent fluids [Von Damm, 1995; Edmonds and Edmond, 1995].

[57] The depth to the seafloor at the EPR where Site 1256 formed is $\sim 2.5 \mathrm{~km}$, and the lower dikes and plutonic section lie $\sim 1 \mathrm{~km}$ subbasement, which would have been at pressures of $\sim 360$ bars at the spreading axis. This is above the critical point pressure for seawater, and the trapping temperatures of the inclusions in quartz veins and vugs range up to $469^{\circ} \mathrm{C}$, spanning across the supercritical two-phase boundary. At 350-360 bars and temperatures of $425^{\circ} \mathrm{C}-440^{\circ} \mathrm{C}$, supercritical phase separation leads to formation of brines having salinities of $7-10$ wt $\% \mathrm{NaCl}$ equivalent plus a vapor phase having salinity of $\sim 1 \mathrm{wt} \% \mathrm{NaCl}$, as observed in other oceanic sheeted dikes and plutonic rocks [Schöps and Herzig, 1990; Kelley et al., 1993; Saccocia and Gillis, 1995; Heft et al., 2008]. If some cooling of fluids is taken into account, these temperatures and salinities are comparable to those for the inclusions in quartz veins and vugs from Hole 1256D.

[58] Quartz in the felsic veins and gabbro groundmass contain lower-salinity inclusions similar to those in the quartz veins, but also contain hyper- saline inclusions that range to $\sim 50$ wt $\% \mathrm{NaCl}$ (Table 2). Given their occurrence in magmatic veins and groundmass, these hypersaline inclusions probably record magmatic fluids. One hydrothermal quartz vein in gabbro (at $1446.04 \mathrm{mbsf}$ ) also contains a component of high-salinity inclusions (Table 2). Such brines can form through supercritical phase separation of seawater at 350-400 bars and temperatures of $450^{\circ} \mathrm{C}-500^{\circ} \mathrm{C}$ [Kelley et al., 1993; Saccocia and Gillis, 1995], but could also reflect input of magmatic fluids into circulating hydrothermal fluids within the plutonic section.

[59] The quartz-forming fluids can be further constrained with oxygen isotope analyses. Using average trapping temperatures of fluid inclusions in quartz veins and $\delta^{18} \mathrm{O}$ values of quartz adjacent to the fluid inclusion samples, application of the quartz-water oxygen isotope fractionation of Sharp and Kirschner [1994] shows that fluids in equilibrium with quartz veins had $\delta^{18} \mathrm{O}$ values of $1.4 \% 0^{-}$ $3.5 \%$ (Table 3). Assuming that quartz from a tonalite vein (at 1357.99 mbsf) was in equilibrium with an aqueous fluid and using temperature of the lower-salinity inclusions in an adjacent quartz sample, the fluid would have had a $\delta^{18} \mathrm{O}$ value of $1.0 \%$ (Tables 2 and 3 ).

[60] Temperatures and fluid compositions can also be estimated using quartz-epidote mineral pairs. Applying the quartz-epidote temperature fractionation of Matthews and Schliestedt [1984] and using a pistacite content of 0.29 , one quartz-epidote pair from an alteration patch in the dikes (at $1256 \mathrm{mbsf}$ ) gives a temperature of $354^{\circ} \mathrm{C}$ (Table 3). The fluid in equilibrium with this quartz would have had $\delta^{18} \mathrm{O}=0.4 \%$ [Sharp and Kirschner, 1994]. A second quartz-epidote pair from a quartz-epidote band in a gabbro at 1469 mbsf yields an equilibrium temperature of $228^{\circ} \mathrm{C}$ and a fluid $\delta^{18} \mathrm{O}$ of $-2.8 \%$ (Table 3 ). This temperature estimate is low for epidote formation, and the negative fluid $\delta^{18} \mathrm{O}$ value is unreasonable in rocks dominated by hydrothermal alteration by seawater at temperatures $>250^{\circ} \mathrm{C}$, where fluid-rock interactions lead to ${ }^{18} \mathrm{O}$ enrichment of seawater fluids. Quartz in this sample has highly variable grain size suggesting multiple generations of quartz, and that this mineral pair does not represent equilibrium.

[61] The quartz-forming fluids in the dikes and plutonic section had $\delta^{18} \mathrm{O}$ values of $0.4 \%$ - $3.5 \%$, similar to seafloor hydrothermal vent fluids $\left(\sim 0.5 \% \%_{0}-2 \%\right.$ ) [Shanks, 2001]. Assuming an intermediate $\delta^{18} \mathrm{O}$ value of $1.5 \%$ o for hydrothermal fluids, other quartz samples in the sheeted dikes and plutonic section 


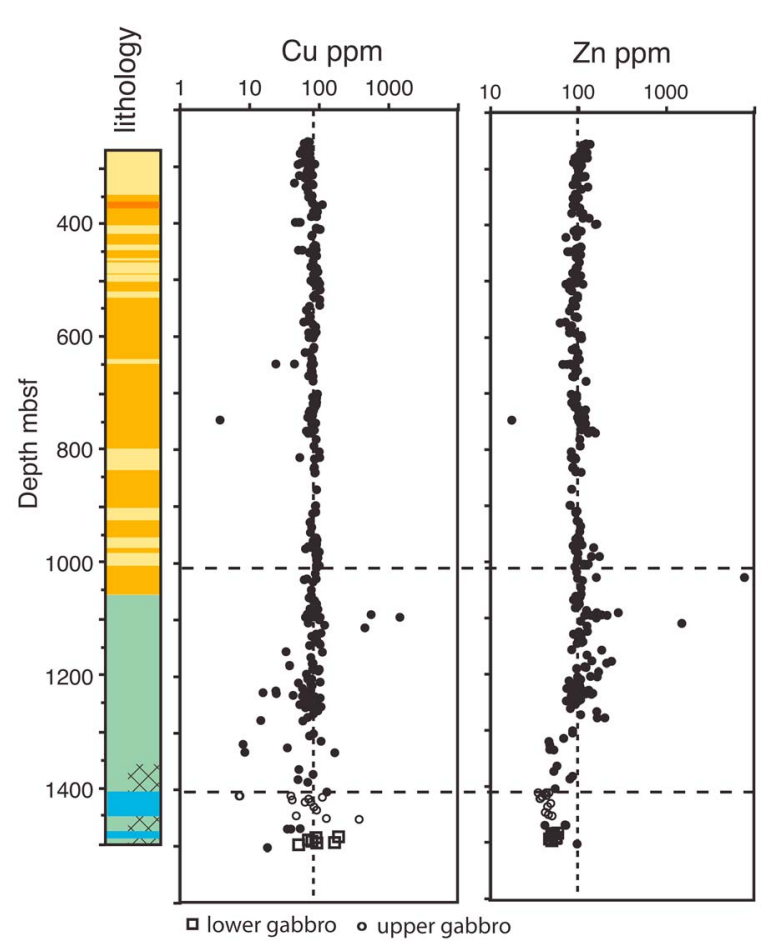

Figure 14. Bulk rock metal contents versus depth. Note metal enrichments in upper dikes and metal depletions in lower dikes and plutonic section. Additional metal enrichments of upper dikes are indicated by local $\mathrm{Fe}, \mathrm{Cu}$, and $\mathrm{Zn}$ sulfides in veins. Dashed vertical lines for reference. There is little variation in metal contents with fractionation in lavas and dikes, so plots of changes in metal contents look the same. See section 4.5 for discussion (D. A. H. Teagle, unpublished data, 2010). Lithology as in Figure 2.

formed in equilibrium with such fluids at temperatures of $320^{\circ} \mathrm{C}-450^{\circ} \mathrm{C}$ (Figure 13 and Table 3).

\subsection{Mineralization and Metal Mobility in the Sheeted Dikes and Plutonic Section}

[62] Local sulfide mineralization and metal enrichments occur in the upper dikes, as indicated by elevated $\mathrm{Zn}$ and $\mathrm{Cu}$ contents at $\sim 1025-1110 \mathrm{mbsf}$ (Figure 14). Veins of quartz + pyrite \pm chalcopyrite \pm sphalerite are also common down to $\sim 1200 \mathrm{mbsf}$, documenting minor local metal enrichments not shown by the bulk rock analyses in Figure 14. Data for fluid inclusions and oxygen isotopes presented above show that hydrothermal fluids had temperatures, salinities, and oxygen isotope compositions similar to those of seafloor vent fluids. The association of metal sulfides with quartz in veins indicates that these subsurface fluids were also enriched in metals and sulfide like the vent fluids. The common occurrence of sulfide mineraliza- tion and anhydrite in brecciated dike margins suggests that this hydrothermal activity was coeval with dike intrusion at the spreading axis [Teagle and Expedition 309/312 Scientists, 2006].

[63] The mineralized breccia near the top of the lavas-dikes transition coincides with the downward change from low-temperature seawater alteration to higher-temperature hydrothermal alteration. The intense sulfide mineralization, stepwise increase in alteration grade and temperatures, plus a peak in whole-rock $\mathrm{Sr}$ isotope ratios in this zone [Harris et al., 2008], indicate that alteration and mineralization of the breccia occurred in a mixing zone between generally upwelling hydrothermal fluids in the dikes and cooler seawater solutions in the overlying volcanic section.

[64] The dikes exhibit variable depletions in $\mathrm{Cu}$ below $\sim 1150$ mbsf and have low $\mathrm{Zn}$ contents below 1300 mbsf (Figure 14). These metal depletions reflect leaching of metals during hydrothermal alteration at high temperatures $\left(>350^{\circ} \mathrm{C}\right)$, where the solubility of metals in hydrothermal fluids increases significantly [Seewald and Seyfried, 1990]. Metal depletions roughly coincide with a change in silicate alteration at $\sim 1300$ mbsf: below this depth chlorite diminishes and amphibole increases in abundance, and the dikes are more intensely recrystallized. The granoblastic dikes (below $1360 \mathrm{mbsf}$ ) and the dike screen between the two gabbro units have low $\mathrm{Cu}$ and $\mathrm{Zn}$ contents, but because these rocks exhibit only slight hydration to amphibole, the metal losses must have occurred during the initial stage of hydrothermal alteration, prior to contact metamorphism.

[65] The variable $\mathrm{Cu}$ and $\mathrm{Zn}$ contents of the plutonic rocks in part reflect igneous processes, but also result from hydrothermal leaching of metals. Moderately altered gabbros having high $\mathrm{Cu}$ contents $(>150 \mathrm{ppm})$ contain mainly recrystallized igneous sulfides, reflecting igneous accumulation of $\mathrm{CuFe}$ and Fe sulfides. An oxide diorite at $1411.16 \mathrm{mbsf}$ contains only $7 \mathrm{ppm} \mathrm{Cu}$, in part reflecting the leaching of metals from the highly altered rock.

[66] The metal losses in the lower dikes and plutonic section are consistent with observations of other oceanic and ophiolitic sections [Alt et al., 1996; Alt and Anderson, 1991; Harper et al., 1988; Nehlig et al., 1994; Gillis, 1995; Gillis et al., 2001; Heft et al., 2008], and with this portion of the crust being the deep "root zone" of submarine hydrothermal systems. Inclusion-rich anorthite rims around magmatic plagioclase that occur in the hydrothermal root zone in the lower dikes of Hole 504B and in Oman [Vanko and Laverne, 1998] have not been 
observed in Hole 1256D, perhaps because equivalent rocks have been recrystallized to granoblastic assemblages.

\subsection{Anhydrite Formation in Lavas and Dikes}

[67] The lower lavas and upper dikes at Site 1256 are the sites of anhydrite precipitation (Figure 2). Using the sulfate-water oxygen isotope fractionation of Chiba et al. [1981] and assuming equilibrium with seawater, anhydrite formed at temperatures of $36^{\circ} \mathrm{C}-408^{\circ} \mathrm{C}$, with most samples falling in the range $105^{\circ} \mathrm{C}-210^{\circ} \mathrm{C}$ (Figure 13 and Table 3). Anhydrites shallower than $1100 \mathrm{mbsf}$ in the upper dikes are significantly enriched in ${ }^{18} \mathrm{O}$ relative to seawater sulfate $\left(10.9 \%{ }^{\circ}-16.3 \%\right.$ versus $9.3 \%$, respectively) [Lloyd, 1968], and have equilibrium temperatures of $105^{\circ} \mathrm{C}-180^{\circ} \mathrm{C}$. Formation of anhydrite at these temperatures is consistent with heating of sulfatebearing seawater fluids that may also have been enriched in Ca through reaction with basalt [Shanks et al., 1981]. The kinetics of sulfur and oxygen exchange in sulfate are slow, however, at these temperatures and at the $\mathrm{pH}$ expected during basalt seawater reactions $\left(\sim 6\right.$ at $\left.150^{\circ} \mathrm{C}\right)$ [Seyfried and Bischoff, 1979; Chiba et al., 1981]. The measured sulfate $\delta^{18} \mathrm{O}$ values thus may represent only partial reaction toward higher equilibrium $\delta^{18} \mathrm{O}$ values at temperatures less than those calculated assuming equilibrium.

[68] Several anhydrites below $1100 \mathrm{mbsf}$ in the upper dikes are generally only slightly enriched in ${ }^{18} \mathrm{O}$ compared to seawater sulfate, yielding equilibrium temperatures of $179^{\circ} \mathrm{C}-211^{\circ} \mathrm{C}$ (Table 3 and Figure 13). These slight ${ }^{18} \mathrm{O}$ enrichments could result from higher reaction temperatures than the shallower anhydrites, but because of the slow reaction rates at these conditions, the data may reflect kinetic effects. Seawater sulfate that reacted with basalt at temperatures similar to the shallower anhydrites, but to a lesser extent, would show the slight ${ }^{18} \mathrm{O}$ enrichments like the deeper anhydrites. The high- $\delta^{18} \mathrm{O}$ anhydrite in a chlorite + pyrite + anhydrite vein at $1166 \mathrm{~m}$ is in equilibrium with seawater at $36^{\circ} \mathrm{C}$ : this sample must have formed from seawater sulfate that was highly reacted (near equilibrium) at low temperatures and which was then heated and mixed with hydrothermal fluids to form anhydrite. In contrast, anhydrite with chalcopyrite in a brecciated dike margin at 1114 mbsf has very low $\delta^{18} \mathrm{O}(2.2 \%)$ reflecting high-temperature reactions $\left(408^{\circ} \mathrm{C}\right.$ if in equilibrium with seawater) [Chiba et al., 1981].
[69] The anhydrites in Hole 1256D thus formed over a range of temperatures and with varying reaction histories, but are generally consistent with heating of seawater fluids and mixing with hydrothermal fluids as seawater penetrated downward into hotter dikes as also observed in Hole 504B [Teagle et al., 1998]. Prior to anhydrite formation, the seawaterderived fluids reacted with basalt to varying degrees at temperatures $<200^{\circ} \mathrm{C}$. Anhydrite could reflect rapid precipitation at high temperatures during heating and mixing, freezing in the oxygen isotope exchange effects that occurred at lower temperatures. Alternatively, the temperatures could reflect equilibrium during anhydrite formation as seawater penetrated to greater depths as the system waned and cooled (Figure 13).

\subsection{Late Alteration Effects in Dikes and Plutonic Section}

[70] Generally late alteration phases in veins and rocks include anhydrite, prehnite, laumontite, and calcite. With the exception of anhydrite, formation of these phases reflects overall decreasing temperatures and more evolved hydrothermal fluids (e.g., $\mathrm{Mg}$-depleted, elevated $\mathrm{Ca}$ and $\mathrm{pH}$ ) [Seyfried et al., 1999]. Prehnite is stable relative to epidote at higher $\mathrm{Ca}$ activity and $\mathrm{pH}$ and at lower temperatures [Rose and Bird, 1987], and laumontite forms in geothermal systems at temperatures below about $240^{\circ} \mathrm{C}$ [Neuhoff and Bird, 2001]. Minor chlorite-smectite and smectite occur locally in the dikes and plutonic section, and reflect lower alteration temperatures $\left(<200^{\circ} \mathrm{C}\right)$ and/or incomplete reaction of olivine and orthopyroxene to chlorite [Alt et al., 1986].

\subsection{Low-Temperature Alteration of the Volcanic Section}

[71] The mineralogy and hydrothermal processes in the volcanic section are generally typical of lowtemperature alteration of upper oceanic basement (summary by Alt [2004]). Temperatures can be estimated from oxygen isotope data for secondary vein minerals. Assuming equilibrium with seawater $(0 \%)$, saponite, celadonite, quartz, and chalcedony formed at temperatures of $50^{\circ} \mathrm{C}-125^{\circ} \mathrm{C}$, generally increasing downward, and ranging up to higher temperatures $\left(185^{\circ} \mathrm{C}\right)$ near the base of the lavas (Table 3 and Figure 13).

[72] Petrographic relationships show that the earliest alteration was the formation of dark celadonitebearing alteration halos along fractures. These 
Fast spreading rate

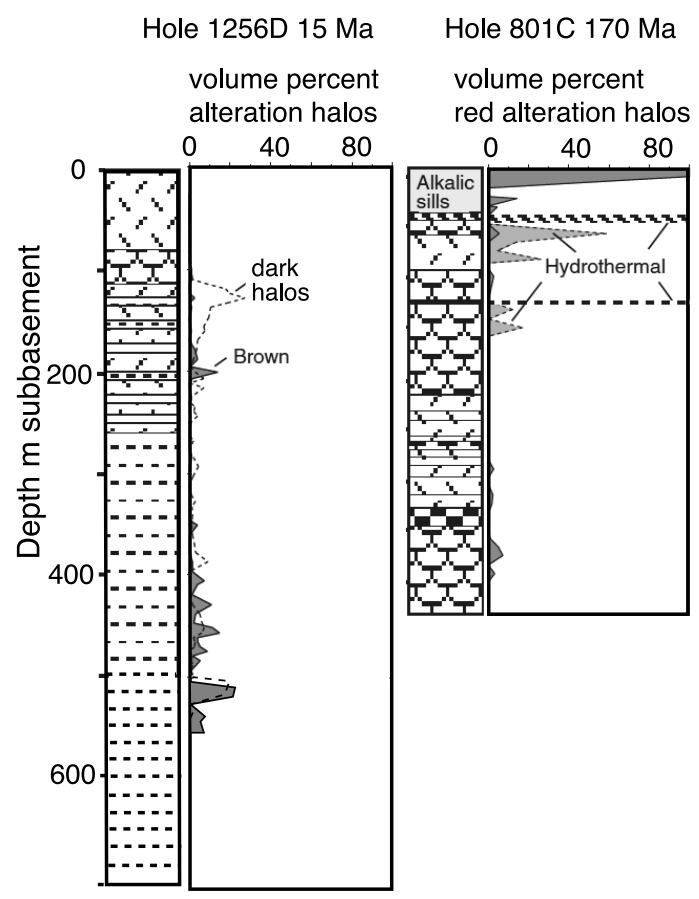

Intermediate spreading rate

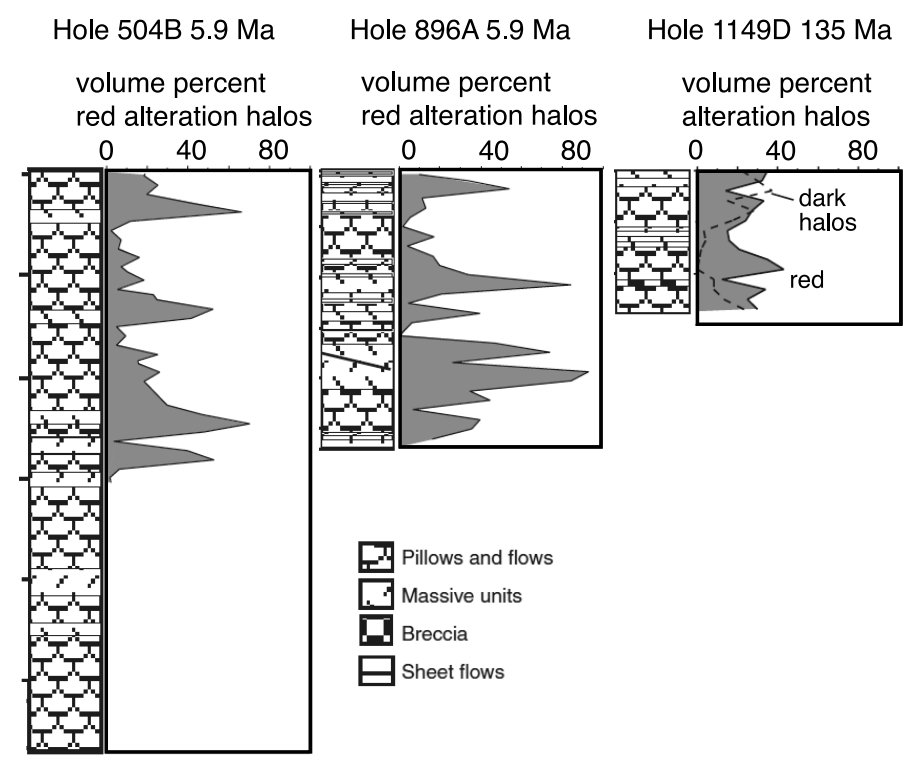

Figure 15. Distribution of alteration halos in upper oceanic basement. Alteration halos in crust formed at fast spreading rates are less abundant than those in basement formed at intermediate spreading rates, reflecting more rapid sealing of basement by sediment at fast spreading rates. See section 4.8 for discussion. [After Alt et al., 1996; Alt, 2004.]

alteration halos form in very young basalts $\left(<10^{5} \mathrm{yrs}\right.$ old) and result in additions of iron, silica, and alkalis to the rock [Alt, 2004]. Celadonite in these halos forms from upwelling distal hydrothermal fluids. Mixing of upwelling black-smoker-type hydrothermal fluids in the subsurface causes deposition of metal sulfides at depth, and the resulting cool $\left(\sim 10^{\circ} \mathrm{C}-100^{\circ} \mathrm{C}\right)$ mixed fluids are enriched in iron, silica, and alkalis compared to seawater and to ridge flank basement fluids [Edmond et al., 1979a, 1979b; Wheat and Mottl, 2000]. Such mixed fluids are manifest at the ridge crest as the diffuse venting that surrounds black smokers and that occurs sporadically between hydrothermal vent sites. The heterogeneity of diffuse flow in the subsurface contributes to variability in the thickness and distribution of the dark celadonitic alteration halos.

[73] Petrographic observations show that, subsequently, iron oxyhydroxides formed in unaltered rocks or superimposed on celadonitic alteration halos along fractures. It is inferred that this results from flow of cold seawater through the rocks [e.g., Alt, 2004]. Saponite, rich in ferrous iron, and pyrite may have formed simultaneously with iron oxyhydroxides, but in the adjacent host rock at lower seawater/rock ratios and under more reduc- ing conditions. Circulation throughout the volcanic section evolved to lower seawater/rock ratios and reducing conditions as indicated by the ubiquitous late saponite \pm pyrite rocks and veins. Small amounts of late carbonates and zeolites formed from more highly evolved (Mg-depleted, elevated $\mathrm{pH})$ low-temperature seawater-derived fluids [Alt, 2004].

[74] Compared to crust formed at intermediate spreading rates, the abundance of red ironoxyhydroxide-rich alteration halos is much lower at Site 1256 and in the one other deep drillhole in fast spread crust (Hole 801C, Figure 15). This likely reflects sealing of basement to seawater access by sediment blanketing the smoother basement topography at fast spreading rates [Alt and Teagle, 2003]. Volcanic eruptive style may also play a role, with more abundant pillow basalts at intermediate spreading rates perhaps providing greater permeability and enabling more seawater circulation than do sheet and massive flows that dominate at fast spreading rates. The massive ponded lava flow capping the section at Site 1256 may have restricted flow in the immediately underlying rocks, but upper basement flow is generally horizontal over the scale of tens of kilometers, controlled by permeable horizons at 


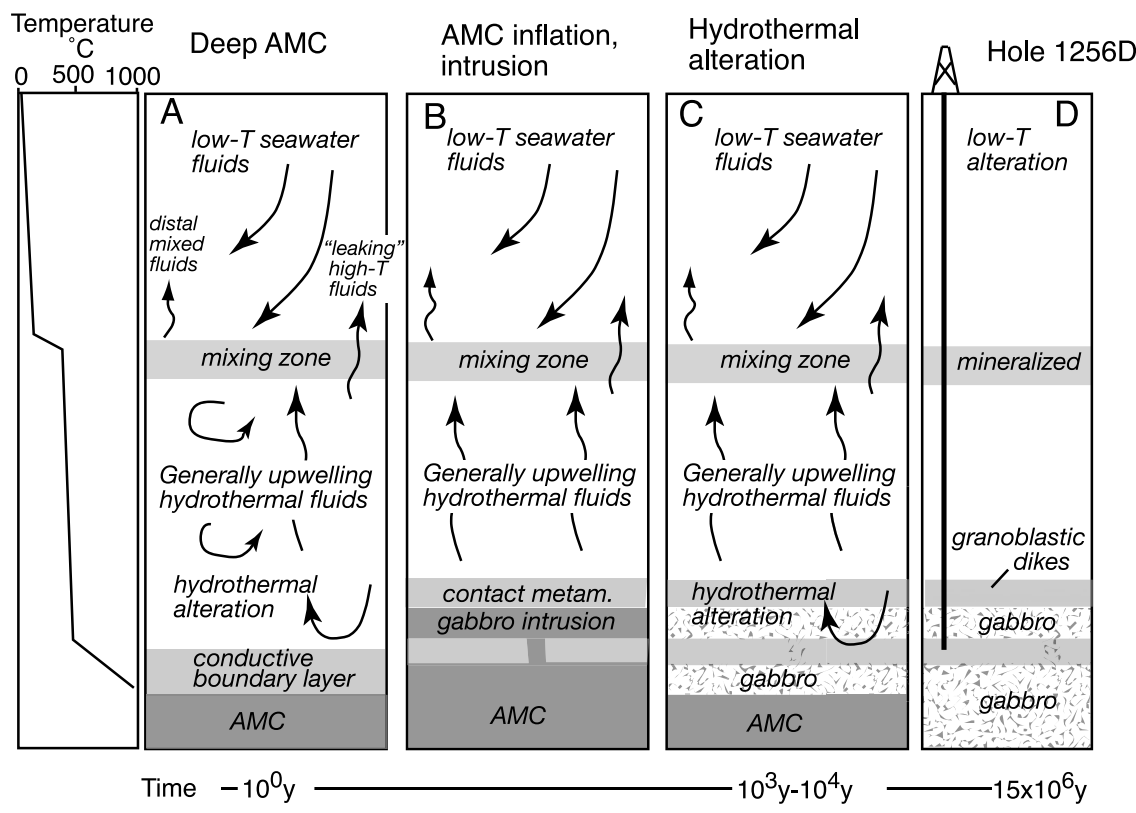

Figure 16. Summary of alteration processes at Site 1256. (a) Conductive boundary layer separates deep axial magma chamber (AMC) from high-temperature hydrothermal alteration and leaching of metals in the lower dikes. Generally upwelling hydrothermal fluids in the dikes mix in the transition zone with cooler seawater circulating in the overlying lavas. Distal mixed fluids percolate upward to alter basalt lavas locally and vent as diffuse flow on the seafloor. Some high-T fluids leak upward to locally alter lavas. Idealized temperature profile at left shows steps in thermal gradient across hydrothermal mixing zone and conductive boundary layer. (b) Inflation of AMC, intrusion of gabbro units into lower dikes, and contact metamorphism producing granoblastic dikes. (c) Crystallization and cooling of gabbro intrusions and upper $\mathrm{AMC}$, with downward penetration of hydrothermal fluids and hydration of granoblastic dikes and plutonic section. Gabbro crystallized from upper AMC now acts as conductive boundary layer. (d) Present alteration stratigraphy at Site 1256. Time line based on $200 \mathrm{~mm} \mathrm{yr}^{-1}$ full spreading rate and $1-2 \mathrm{~km}$ width of AMC.

shallow (100 s of m) depth [Fisher, 2005], so it is unlikely that the massive flow affected alteration of rocks hundreds of meters below.

[75] Oxygen isotope data indicate that temperatures generally increased downward in the volcanic section, with a stepwise increase to hydrothermal temperatures across the top portion of the lavas-dikes transition (Figure 13). The presence of local chlorite and chlorite-smectite in the lower lavas suggests locally higher temperatures $\left(>\sim 200^{\circ} \mathrm{C}\right)$, probably related to flow of higher-temperature hydrothermal fluids "leaking" upward across the lithologic transition from the underlying dikes. The narrow chloritesmectite-bearing green-gray halos and pyrite-bearing halos at the base of the lavas may also be related to "upward leaking" higher-temperature fluids.

[76] The intense alteration of the $41 \mathrm{~cm}$ interval at $648 \mathrm{mbsf}(90 \%$ altered to celadonite, beidellite, $\mathrm{K}$-feldspar, iron oxyhydroxide, quartz, and calcite) reflects focused fluid flow. The enrichments of K, $\mathrm{Fe}$ and $\mathrm{Si}$ in these rocks [Teagle and Expedition 309/312 Scientists, 2006] are inconsistent with seawater but are consistent with flow of cooler, mixed hydrothermal fluids derived from the mineralized mixing zone below. The mineralogy of these intensely altered rocks is identical to that of brecciated pillow lavas beneath a low-temperature $\left(\sim 60^{\circ} \mathrm{C}\right)$ seafloor iron-silica deposit in ODP Hole $801 \mathrm{C}$, where the link between this intense alteration and distal hydrothermal fluids is clear [Alt and Teagle, 2003].

\subsection{Summary: Structure and Evolution of the Hydrothermal System at Site 1256}

[77] In this section we combine the observations and interpretations for the different basement sections into an integrated view of the hydrothermal system at Site 1256, documenting interactions between hydrothermal circulation, basement lithology, and magmatism (Figure 16).

[78] The earliest reactions in the cored section involved hydrothermal alteration of the dike section above a melt lens at the EPR. Hydrothermal fluid circulation in the dikes is separated from the melt lens by a conductive boundary layer, where heat is transferred by conduction from magma to the 
overlying convecting hydrothermal system [Gillis, 2008]. Hydrothermal alteration of the lower dikes at Site 1256 occurred at relatively high temperatures $\left(>350^{\circ} \mathrm{C}\right)$, mobilizing metals from these rocks. Intrusion of the two gabbro bodies into the lower sheeted dikes and contact metamorphism of these rocks at temperatures of $\sim 800^{\circ} \mathrm{C}-900^{\circ} \mathrm{C}$ may be related to inflation of the axial melt lens. This produced granoblastic textures in the lower dikes, the dike screen, and in the lower gabbro unit, with the previous hydrothermal alteration controlling the high-temperature recrystallization effects. Hydrous partial melting of altered dikes also occurred [Koepke et al., 2008; France et al., 2009]. This contact metamorphism represents the upward migration of the conductive boundary layer into hydrothermally altered rocks [Teagle and Expedition 309/312 Scientists, 2006; Koepke et al., 2008]. Hydrothermal circulation and alteration later penetrated downward into the contact metamorphosed lower dikes and plutonic section as these rocks cooled, with initial hydrothermal fluid penetration into the granoblastic dikes at temperatures of $700^{\circ} \mathrm{C}-800^{\circ} \mathrm{C}$. The inferred highest temperatures of fluid reactions in the gabbros as recorded by amphibole formation were $830^{\circ} \mathrm{C}-910^{\circ} \mathrm{C}$, reflecting late magmatic fluids or the earliest penetration of seawater fluids [Coogan et al., 2001; Koepke et al., 2008].

[79] Contact hornfels metamorphism of basal dikes, hydrous partial melting, highly variable gabbroic rocks, and complex intrusive relationships have been documented at this lithostratigraphic level elsewhere in ocean crust and ophiolites [Gillis and Roberts, 1999; Gillis, 2008; Nicolas et al., 2008; France et al., 2009]. This "root zone" of the sheeted dikes is $\sim 100 \mathrm{~m}$ thick, with contact metamorphic aureoles $\sim 40 \mathrm{~m}$ thick that migrate vertically as much as $200-400 \mathrm{~m}$ as magmatism waxes and wanes. Temperatures of contact metamorphism $\left(756^{\circ} \mathrm{C}-1024^{\circ} \mathrm{C}\right)$ and of initial hydration $\left(701^{\circ} \mathrm{C}-\right.$ $997^{\circ} \mathrm{C}$ ) in these rocks [Gillis, 2008] are similar to those estimated for Site 1256.

[80] Initial hydrothermal alteration of the shallower dikes involved formation of amphibole + magnetite, albite-oligoclase, chlorite, and titanite. Hydrothermal fluids in this section rapidly evolved to upwelling fluids similar to seafloor vent fluids, leading to mineralization at the lavas-dikes boundary where hydrothermal fluids mixed with cooler seawater fluids circulating in the overlying lavas. Quartz + sulfide \pm anhydrite veins also formed locally in the upper dikes, with anhydrite recording prior evolution of seawater fluids at temperatures generally less than $200^{\circ} \mathrm{C}$. Up to $\sim 500 \mathrm{~m}$ of lavas accumulated while Site 1256 was at the spreading axis [Tominaga et al., 2009]. Distal mixed hydrothermal fluids percolating upward from the mixing zone in the lavas-dikes transition caused formation of the dark celadonite-bearing alteration halos along flow pathways in the volcanic section and may have fed diffuse venting at the seafloor. Local focused flow of these distal hydrothermal fluids and mixing with seawater led to localized intense alteration of lavas to celadonite $+\mathrm{K}$-feldspar + beidellite + iron oxyhydroxide assemblages, which are now deep in the volcanic section (at $648 \mathrm{mbsf}$ ), but which were probably altered at or near the seafloor at the spreading axis.

[81] Hydrothermal activity in the dike complex was likely coeval with dike intrusion, as indicated by hydrothermal alteration and mineralization of brecciated dike margins, but continued as individual dikes and their surrounding host rocks cooled to greenschist facies conditions. Fluids evolved from early $\mathrm{Mg}$-bearing hydrothermal fluids forming chlorite and amphibole in veins and host rocks at temperatures as high as $\sim 600^{\circ} \mathrm{C}$ to "blacksmoker-like" hydrothermal fluids at temperatures of $320^{\circ} \mathrm{C}-450^{\circ} \mathrm{C}$. These mineralizing fluids had variable salinities resulting from processes related to supercritical phase separation in the lower dikes and plutonic section. Anhydrite formed in fractures in the lower lavas and upper dikes as partly reacted seawater penetrated downward and was heated and mixed with hot hydrothermal fluids.

[82] Prehnite and laumontite formed in the dikes and plutonic section from more evolved hydrothermal fluids as the hydrothermal system cooled. With further cooling, minor late chlorite-smectite and smectite formed locally in the dikes and plutonic section through hydration of relict olivine and orthopyroxene. The current temperature at the base of the cored section is $\sim 100^{\circ} \mathrm{C}$, and these phases could be forming at the present time.

[83] Fluids in the volcanic section evolved to more seawater dominated, with formation of iron oxyhydroxides in the rocks via flow along the same pathways as previous alteration. There is much less oxidation in Site 1256 lavas compared to crust formed at intermediate spreading rates, and where present it is spatially related to zones of concentrated subvertical fracturing. This lack of oxidative low-temperature alteration mostly likely reflects the efficient sealing of the relatively smooth basement by sediment. Only minor amounts of late carbonates and zeolites are present, perhaps related to sealing of basement and restriction of fluid flow. 
It is not known precisely when the seawater oxidation occurred, but there is no present evidence for continuing fluid circulation or advective heat transport at Site 1256 [Wilson et al., 2003].

\subsection{Comparison With Current Models}

[84] In a general model for the subsurface of submarine hydrothermal systems, Alt [1995] documented the effects of early alteration during seawater recharge followed by diffuse hydrothermal upflow and mineralization during subsurface mixing with seawater at the lavas-dikes boundary in ocean crust and ophiolites. It was proposed that this process is responsible for the observed stepped thermal gradient. Recent work based on new observations of altered crust have suggested that such stepped thermal gradients can only be maintained if all hydrothermal alteration occurs during fluid upflow [Barker et al., 2008; Coogan, 2008; Gillis, 2008; Heft et al., 2008].

[85] Heft et al. [2008] show that effects of upflow in the dikes are variable. In some areas fluid flow is of sufficiently short duration that only the initial alteration stages are observed, like the "background" alteration at Site 1256. Elsewhere, upflow develops and continues long enough for fluids to achieve black-smoker-like compositions and deposit veins of quartz \pm sulfide, as observed at Site 1256. Variable focusing of upflow results in differing intensities of alteration and mineralization in fault zones and during mixing at the lavas-dikes boundary [Honnorez et al., 1985; Saccocia and Gillis, 1995; Gillis, 1995; Gillis et al., 2001; Heft et al., 2008; Barker et al., 2010].

[86] Results from Site 1256 agree in general with these models. In particular, the upper dike section is characterized by the effects of hydrothermal upflow and mixing with seawater at the lava-dikes boundary. There is evidence for trace amounts of lower-temperature $\left(<200^{\circ} \mathrm{C}\right)$ alteration in the plutonic section, but there is no evidence for significant low-temperature fluid flow in these rocks or the dike section.

[87] There is little anhydrite at depth in the Site 1256 dikes and none in the plutonic section, in contrast to what would be expected from significant circulation of little-reacted seawater at these depths. The main zone of anhydrite formation is within the upper dikes (at 1100-1200 mbsf), where seawater fluids were heated and mixed with hydrothermal fluids. This is consistent with observations of anhydrite in the one other drillhole to penetrate this lavadike boundary [Alt et al., 1986; Teagle et al., 1998], and as predicted for the zone where seawater is heated as temperatures increase downward [Mottl, 1983].

[88] Recent 3-D modeling of hydrothermal circulation at spreading axes shows cylindrical focused upflow zones, surrounded by dispersed downward recharge of seawater [Coumou et al., 2008]. The upflow zones in the models are unstable, and migrate along-axis, consistent with interpretations of microearthquake data [Tolstoy et al., 2008]. These fluid circulation models are based on a uniform basement permeability, and result in the $100^{\circ} \mathrm{C}$ isotherms outside the upflow zones being quite deep in the basement [Coumou et al., 2008]. In contrast, circulation models that take into account the stepwise decrease in permeability downward from lavas to dikes result in shallower isotherms, with a step-like temperature increase corresponding to the lavas-dikes transition, as observed in oceanic basement [Rosenberg et al., 1993]. In these models greater volumes of fluid circulate through the lavas, maintaining low temperatures there, whereas the dikes remain hot. Evidence from anhydrite in Hole $1256 \mathrm{D}$ suggests that anhydrite precipitates as seawater, partly reacted in the volcanic section, penetrates downward from the cooler lavas into the hot dikes. This could happen around the periphery of upflow zones, or at the site of a former upflow zone as these migrate along axis or as a crustal section moves away from focused upflow as the result of seafloor spreading.

\section{Concluding Remarks}

[89] Alteration of the upper crustal section at Site 1256 documents the thermal and chemical structure of a submarine hydrothermal system, and the evolution of fluid-rock interactions with time. A critical part of this is the interplay between fluid flow, lithology, and magmatism, from the mobile top of an axial magma chamber up to the seafloor. Results are generally consistent with current models for fast spread crust but there is little evidence for significant low-temperature fluid flow or significant cooling deep in the dikes. Planned deeper penetration at this site will allow evaluation of models for fluid flow, and chemical and heat transport from the lower oceanic crust.

\section{Acknowledgments}

[90] This research used samples provided by the Ocean Drilling Program (ODP) and Integrated Ocean Drilling Program 
(IODP), with financial support by the U.S. National Science Foundation (OCE0647784) and JOI. The paper benefited significantly from thorough reviews by Kathryn Gillis and Peter Schiffman.

\section{References}

Alt, J. C. (1995), Subseafloor processes in mid-ocean ridge hydrothermal systems, in Seafloor Hydrothermal Systems: Physical, Chemical, and Biological Interactions, Geophys. Monogr. Ser., vol. 91, edited by S. Humphris et al., pp. 85-114, AGU, Washington, D. C.

Alt, J. C. (2004), Alteration of the upper oceanic crust: Mineralogy, chemistry, and processes, in Hydrogeology of the Oceanic Lithosphere, edited by H. Elderfield and E. Davis, pp. 456-488, Cambridge Univ. Press, New York.

Alt, J. C., and T. F. Anderson (1991), The mineralogy and isotopic composition of sulfur in Layer 3 gabbros from the Indian Ocean, ODP Hole 735B, Proc. Ocean Drill. Program Sci. Results, 118, 113-125.

Alt, J. C., and C. Laverne (2006), Chemical compositions of secondary minerals from Site 1256 basement, ODP Leg 206 [online], Proc. Ocean Drill. Program Sci. Results, 206, $16 \mathrm{pp}$. (Available at http://www-odp.tamu.edu/publications/ 206_SR/003/003.htm)

Alt, J. C., and D. A. H. Teagle (2000), Hydrothermal alteration and fluid fluxes in ophiolites and ocean crust, in Ophiolites and Oceanic Crust: New Insights From Field Studies and the Ocean Drilling Program, edited by Y. Dilek et al., Spec. Pap. Geol. Soc. Am., 349, 273-282.

Alt, J. C., and D. A. H. Teagle (2003), Hydrothermal alteration of upper oceanic crust formed at a fast spreading ridge: Mineral, chemical, and isotopic evidence from ODP Site 801, Chem. Geol., 201, 191-211, doi:10.1016/S00092541(03)00201-8.

Alt, J. C., J. Honnorez, L. Laverne, and R. Emmermann (1986), Hydrothermal alteration of a $1 \mathrm{~km}$ section through the upper oceanic crust, DSDP Hole 504B: The mineralogy, chemistry, and evolution of seawater-basalt interactions, J. Geophys. Res., 91, 10,309-10,335, doi:10.1029/ JB091iB10p10309.

Alt, J. C., et al. (1996), Hydrothermal alteration of a section of upper oceanic crust in the eastern equatorial Pacific: A synthesis of results from Site 504 (DSDP legs 69, 70, and 83, and ODP legs 111, 137, 140, and 148), Proc. Ocean Drill. Program Sci. Results, 148, 417-434.

Andersen, D. J., D. H. Lindsley, and P. M. Davidson (1993), QUILF: A Pascal program to assess equilibria among Fe$\mathrm{Mg}-\mathrm{Mn}-\mathrm{Ti}$ oxides, pyroxenes, olivine, and quartz, Comput. Geosci., 19, 1333-1350, doi:10.1016/0098-3004(93)90033-2.

Banerjee, N. R., and K. M. Gillis (2001), Hydrothermal alteration in a modern suprasubduction zone: The Tonga forearc crust, J. Geophys. Res., 106(B10), 21,737-21,750, doi:10.1029/2001JB000335.

Barker, A. K., L. A. Coogan, K. M. Gillis, and D. Weis (2008), Strontium isotope constraints on fluid flow in the sheeted dike complex of fast spreading crust: Pervasive fluid flow at Pito Deep, Geochem. Geophys. Geosyst., 9, Q06010, doi:10.1029/2007GC001901.

Barker, A. K., L. A. Coogan, K. M. Gillis, N. W. Hayman, and D. Weis (2010), Direct observation of a fossil hightemperature, fault-hosted, hydrothermal upflow zone in crust formed at the East Pacific Rise, Geology, 38, 379-382, doi:10.1130/G30542.1.
Bickle, M. J., and D. A. H. Teagle (1992), Strontium alteration in the Troodos ophiolite: Implications for fluid fluxes and geochemical transport in mid-ocean ridge hydrothermal systems, Earth Planet. Sci. Lett., 113, 219-237, doi:10.1016/ 0012-821X(92)90221-G.

Bird, D. K., P. Schiffman, W. A. Elders, A. E. Williams, and S. D. McDowell (1984), Calc-silicate mineralization in active geothermal systems, Econ. Geol., 79, 671-695, doi:10.2113/ gsecongeo.79.4.671.

Bischoff, J. L., and R. J. Rosenbauer (1985), An empirical equation of state for hydrothermal seawater (3.2 percent $\mathrm{NaCl})$, Am. J. Sci., 285, 725-763.

Blundy, J., and K. Cashman (2008), Petrologic reconstruction of magmatic system variables and processes, Rev. Mineral. Geochem., 69, 179-239, doi:10.2138/rmg.2008.69.6.

Bodnar, R. J. (2003), Interpretation of data from aqueouselectrolyte fluid inclusions, in Fluid Inclusions; Analysis and Interpretation, Short Course Ser-Mineral. Assoc. of Can., vol. 32, edited by I. M. Samson, A. J. Anderson, and D. Marshall, pp. 81-100, Mineral. Assoc. of Can., London, Ont., Canada.

Brey, G. P., and T. Kohler (1990), Geothermobarometry in four-phase lherzolites II. New thermobarometers, and practical assessment of existing thermobarometers, J. Petrol., 31, 1353-1378.

Buatier, M. D., G. L. Fruh-Green, and A. M. Karpoff (1995), Mechanisms of Mg-phyllosilicate formation in a hydrothermal system at a sedimented ridge (Middle Valley, Juan de Fuca), Contrib. Mineral. Petrol., 122, 134-151, doi:10.1007/ s004100050117.

Butterfield, D. A., R. E. McDuff, M. J. Mottl, M. D. Lilley, J. E. Lupton, and G. J. Massoth (1994), Gradients in the composition of hydrothermal fluids from the Endeavour segment vent field: Phase separation and brine loss, J. Geophys. Res., 99(B5), 9561-9583, doi:10.1029/93JB03132.

Chiba, H., M. Kusakabe, S. Hirano, S. Matsuo, and S. Somiya (1981), Oxygen isotope fractionation factors between anhydrite and water from 100 to $5008 \mathrm{C}$, Earth Planet. Sci. Lett., 53, 55-62, doi:10.1016/0012-821X(81)90025-X.

Clayton, R. N., and T. K. Mayeda (1963), The use of bromine pentafluoride in the extraction of oxygen from oxides and silicates for isotopic analysis, Geochim. Cosmochim. Acta, 27, 43-52, doi:10.1016/0016-7037(63)90071-1.

Coggan, R. M., J. C. Alt, and D. A. H. Teagle (2008), Thermal history of ODP Hole 1256D lower sheeted dikes: Petrology, chemistry and geothermometry of the granoblastic dikes, Eos Trans. $A G U, 89(53)$, Abstract V44B-08.

Coogan, L. A. (2008), Reconciling temperatures of metamorphism, fluid fluxes and heat transport in the upper crust at intermediate- to fast-spreading mid-ocean ridges, Geochem. Geophys. Geosyst., 9, Q02013, doi:10.1029/2007GC001787.

Coogan, L. A., R. N. Wilson, K. M. Gillis, and C. J. Macleod (2001), Near-solidus evolution of oceanic gabbros: Insights from amphibole geochemistry, Geochim. Cosmochim. Acta, 65(23), 4339-4357, doi:10.1016/S0016-7037(01)00714-1.

Coumou, D., T. Driesner, and C. A. Heinrich (2008), The structure and dynamics of mid-ocean ridge hydrothermal systems, Science, 321, 1825-1828, doi:10.1126/science. 1159582 .

Dziony, W., J. Koepke, and F. Holtz (2008), Data report: Petrography and phase analyses in lavas and dikes from the hole 1256D (ODP Leg 206 and IODP Expedition 309, East Pacific Rise) [online], Proc. Integrated Ocean Drill. Program, 309-312, 22 pp. (Available at http://publications. iodp.org/proceedings/309_312/201/201_.htm) 
Edmond, J. M., C. Measures, R. E. McDuff, L. H. Chan, R. Collier, B. Grant, L. I. Gordon, and J. B. Corliss (1979a), Ridge crest hydrothermal activity and the balances of the major and minor elements in the ocean: The Galapagos data, Earth Planet. Sci. Lett., 46, 1-18, doi:10.1016/0012-821X (79)90061-X.

Edmond, J. M., C. Measures, B. Magnum, B. Grant, F. R. Sclater, R. Collier, A. Hudson, L. I. Gordon, and J. B. Corliss (1979b), On the formation of metal-rich deposits at ridge crests, Earth Planet. Sci. Lett., 46, 19-30, doi:10.1016/0012821X(79)90062-1.

Edmonds, H., and J. M. Edmond (1995), A three-component mixing model for ridge-crest hydrothermal fluids, Earth Planet. Sci. Lett., 134, 53-67, doi:10.1016/0012-821X(95) 00115-S.

Ernst, W. G., and J. Liu (1998), Experimental phaseequilibrium study of Al- and Ti-contents of calcic amphibole in MORB - A semiquantitative thermobarometer, Am. Mineral., 83, 952-969.

Fisher, A. T. (2005), Marine hydrogeology: Recent accomplishments and future opportunities, Hydrogeol. J., 13, 69-97, doi:10.1007/s10040-004-0400-y.

France, L., B. Ildefonse, and J. Koepke (2009), Interactions between magma and hydrothermal system in Oman ophiolite and in IODP Hole 1256D: Fossilization of a dynamic melt lens at fast spreading ridges, Geochem. Geophys. Geosyst., 10, Q10O19, doi:10.1029/2009GC002652.

Gillis, K. M. (1995), Controls on hydrothermal alteration in a section of fast-spreading oceanic crust, Earth Planet. Sci. Lett., 134, 473-489.

Gillis, K. M. (2008), The roof of the axial magma chamber: A hornfelsic heat exchanger, Geology, 36, 299-302, doi:10.1130/G24590A.1.

Gillis, K. M., and L. A. Coogan (2002), Anatectic migmatites from the roof of an ocean ridge magma chamber, J. Petrol., 43, 2075-2095, doi:10.1093/petrology/43.11.2075.

Gillis, K. M., and M. Roberts (1999), Cracking at the magmahydrothermal transition: Evidence from the Troodos ophiolite, Earth Planet. Sci. Lett., 169, 227-244, doi:10.1016/ S0012-821X(99)00087-4.

Gillis, K. M., K. Muehlenbachs, M. Stewart, T. Gleeson, and J. Karson (2001), Fluid flow patterns in fast spreading East Pacific Rise crust exposed at Hess Deep, J. Geophys. Res., 106(B11), 26,311-26,329.

Gonfiantini, R., W. Stichler, and K. Rozanski (1995), Standards and intercomparison materials distributed by the International Atomic Energy Agency for stable isotope measurements, in Reference and Intercomparison Materials for Stable Isotopes of Light Elements, IAEA-TECDOC-825, pp. 13-30, Int. At. Energy Agency, Vienna.

Harper, G. D., J. R. Bowman, and R. Kuhns (1988), A field, chemical, and stable isotope study of subseafloor metamorphism of the Josephine ophiolite, California-Oregon, J. Geophys. Res., 93, 4625-4656, doi:10.1029/JB093iB05p04625.

Harris, M., C. E. Smith-Duque, D. A. Teagle, M. J. Cooper, R. M. Coggon and L. Foley (2008), A whole rock strontium isotopic profile through an intact section of upper oceanic crust: ODP Site 1256, Eos Trans. AGU, 89(53), Fall Meet. Suppl., Abstract V44B-07.

Heft, K. L., K. M. Gillis, M. A. Pollock, J. A. Karson, and E. M. Klein (2008), Role of upwelling hydrothermal fluids in the development of alteration patterns at fast spreading ridges: Evidence from the sheeted dike complex at Pito Deep, Geochem. Geophys. Geosyst., 9, Q05O07, doi:10.1029/ 2007GC001926.
Hofmann, A. W., and W. M. White (1982), Mantle plumes from old oceanic crust, Earth Planet. Sci. Lett., 57, 421-436, doi:10.1016/0012-821X(82)90161-3.

Holland, T., and J. Blundy (1994), Non-ideal interactions in calcic amphiboles and their bearing on amphibole-plagioclase thermometry, Contrib. Mineral. Petrol., 116, 433-447, doi:10.1007/BF00310910.

Honnorez, J., J. C. Alt, B. M. Honnorez-Guerstein, C. Laverne, K. Muehlenbachs, J. Ruiz, and E. S. Saltzman (1985), Stockwork-like sulfide mineralization in young oceanic crust: DSDP Hole 504B, Initial Rep. Deep Sea Drill. Proj., 83, 263-282.

Kelley, D. S., K. M. Gillis, and G. Thompson (1993), Fluid evolution in submarine magma-hydrothermal systems at the MidAtlantic Ridge, J. Geophys. Res., 98(B11), 19,579-19,596.

Koepke, J., D. M. Christie, W. Dziony, F. Holtz, D. Lattard, J. Maclennan, S. Park, B. Scheibner, T. Yamasaki, and S. Yamazaki (2008), Petrography of the dike-gabbro transition at IODP Site 1256(equatorial Pacific): The evolution of the granoblastic dikes, Geochem. Geophys. Geosyst., 9, Q07O09, doi:10.1029/2008GC001939.

Laverne, C. (1987), Unusual occurrences of aegirine-augite, fassaite andmelanite in oceanic basalts (DSDP Hole 504B), Lithos, 20, 135-151, doi:10.1016/0024-4937(87)90003-X.

Laverne, C., O. Grauby, J. C. Alt, and M. Bohn (2006), Hydroschorlomite in altered basalts from Hole 1256D, ODP Leg 206: The transition from low-temperature to hydrothermal alteration, Geochem. Geophys. Geosyst., 7, Q10003, doi:10.1029/ $2005 \mathrm{GC} 001180$.

Laverne, C., P. Tartarotti, O. Grauby, and A. C. Siantonas (2007), Chemical composition of minerals from a lava pond, ODP Site 1256(Leg 206) [online], Proc. Ocean Drill. Program Sci. Results, 206, 18 pp. (Available at http://wwwodp.tamu.edu/publications/206_SR/006/006.htm)

Lindsley, D. H. (1983), Pyroxene thermometry, Am. Mineral., $68,477-493$.

Lloyd, R. M. (1968), Oxygen isotope behavior in the sulfatewater system, J. Geophys. Res., 73, 6099-6110, doi:10.1029/ JB073i018p06099.

Matthews, A., and M. Schliestedt (1984), Evolution of the blueschist and greenschist facies rocks of Sifnos, Cyclades, Greece, Contrib. Mineral. Petrol., 88, 150-163, doi:10.1007/ BF00371419.

Mottl, M. J. (1983), Metabasalts, axial hot springs, and the structure of hydrothermal systems at mid-ocean ridges, Geol. Soc. Am. Bull., 94, 161-180, doi:10.1130/0016-7606(1983) 94<161:MAHSAT $>2.0 . \mathrm{CO} ; 2$.

Nehlig, P., T. Juteau, V. Bendel, and J. Cotten (1994), The root zones of oceanic hydrothermal systems: Constraints from the Samail ophiolite (Oman), J. Geophys. Res., 99, 4703-4713, doi:10.1029/93JB02663.

Neuhoff, P. S., and D. K. Bird (2001), Partial dehydration of laumontite: Thermodynamic constraints and petrogenetic implications, Mineral. Mag., 65(1), 59-70, doi:10.1180/ 002646101550127.

Nicolas, A., F. Boudier, J. Koepke, L. France, B. Ildefonse, and C. Mevel (2008), Root zone of the sheeted dike complex in the Oman ophiolite, Geochem. Geophys. Geosyst., 9, Q05001, doi:10.1029/2007GC001918.

Putirka, K. D. (2008), Thermometers and barometers for volcanic systems, Rev. Mineral. Geochem., 69, 61-120, doi:10.2138/rmg.2008.69.3.

Rose, N. M., and D. K. Bird (1987), Prehnite-epidote phase relations in the Nordre Aputiteq and Kruuse Fjord layered gabbros, East Greenland, J. Petrol., 28(6), 1193-1218. 
Rosenberg, N. D., F. J. Spera, and R. M. Haymon (1993), The relationship between flow and permeability field in seafloor hydrothermal systems, Earth Planet. Sci. Lett., 116, 135-153, doi:10.1016/0012-821X(93)90050-J.

Saccocia, P., and K. Gillis (1995), Hydrothermal upflow zones in oceanic crust, Earth Planet. Sci. Lett., 136, 1-16, doi:10.1016/ 0012-821X(95)00155-5.

Savin, S. M., and M. Lee (1988), Isotopic studies of phyllosilicates, in Hydrous Phyllosilicates, Rev. Mineral., vol. 19, edited by W. Bailey, pp. 189-224, Mineral. Soc. of Am., Chelsea, Mich.

Schiffman, P., and G. O. Fridleifsson (1991), The smectitechlorite transition in drillhole NJ-15, Nesjavellir geothermal field, Iceland: XRD, BSE and electron microprobe investigations, J. Metamorph. Geol., 9, 679-696, doi:10.1111/j.15251314.1991.tb00558.x.

Schöps, D., and P. M. Herzig (1990), Sulfide composition and microthermometry of fluid inclusions in the Leg 111 sheeted dike complex of Ocean Drilling Program Hole 504B, Costa Rica Rift, J. Geophys. Res., 95(B6), 8405-8418, doi:10.1029/JB095iB06p08405.

Seewald, J. S., and W. E. Seyfried Jr. (1990), The effect of temperature on metal mobility in subseafloor hydrothermal systems: Constraints from basalt alteration experiments, Earth Planet. Sci. Lett., 101, 388-403, doi:10.1016/0012821X(90)90168-W.

Seyfried, W. E., Jr., and J. L. Bischoff (1979), Low temperature basalt alteration by seawater: An experimental study at $70^{\circ} \mathrm{C}$ and $150^{\circ} \mathrm{C}$, Geochim. Cosmochim. Acta, 43, 1937-1947, doi:10.1016/0016-7037(79)90006-1.

Seyfried, W. E., K. Ding, M. E. Berndt, and X. Chen (1999), Experimental and theoretical controls on the composition of mid-ocean ridge hydrothermal fluids, in Volcanic Associated Massive Sulfide Deposits, Rev. in Econ. Geol., vol. 8, edited by T. Barrie and M. Hannington, pp. 181-200, Soc. of Econ. Geol., Chelsea, Mich.

Shanks, W. C. (2001), Stable isotopes in seafloor hydrothermal systems: Vent fluids, hydrothermal deposits, hydrothermal alteration, and microbial processes, Rev. Mineral. Geochem., 43, 469-525, doi:10.2138/gsrmg.43.1.469.

Shanks, W. C., L. Bischoff, and J. Rosenbauer (1981), Seawater sulfate reduction and sulfur isotope fractionation in basaltic systems: Interaction of seawater with fayalite and magnetite at $200-350^{\circ} \mathrm{C}$, Geochim. Cosmochim. Acta, 45, 1977-1995, doi:10.1016/0016-7037(81)90054-5.

Sharp, Z. D., and D. L. Kirschner (1994), Quartz-calcite oxygen isotope geothermometry: A calibration based on natural isotopic variations, Geochim. Cosmochim. Acta, 58, 4491-4501, doi:10.1016/0016-7037(94)90350-6.

Spooner, E. T. C., and W. S. Fyfe (1973), Sub-sea-floor metamorphism, heat and mass transfer, Contrib. Mineral. Petrol., 42, 287-304, doi:10.1007/BF00372607.
Tatsumi, Y. (1989), Migration of fluid phases and genesis of basalt magmas in subduction zones, J. Geophys. Res., 94, 4697-4707, doi:10.1029/JB094iB04p04697.

Teagle, D. A. H., and Expedition 309/312 Scientists (2006), Superfast Spreading Rate Crust 2 and 3 [online], Proc. Integrated Ocean Drill. Program, 309/312. (Available at http:// iodp.tamu.edu/publications/exp309_312/30912toc.htm)

Teagle, D. A. H., J. C. Alt, and A. N. Halliday (1998), Tracing the chemical evolution of fluids during hydrothermal recharge: Constraints from anhydrite recovered in ODP Hole 504B, Earth Planet. Sci. Lett., 155, 167-182, doi:10.1016/ S0012-821X(97)00209-4.

Teagle, D. A. H., M. J. Bickle, and J. C. Alt (2003), Recharge flux to ocean-ridge black smoker systems: A geochemical estimate from ODP Hole 504B, Earth Planet. Sci. Lett., 210, 81-89, doi:10.1016/S0012-821X(03)00126-2.

Tolstoy, M., F. Waldhauser, D. R. Bohnenstiehl, R. T. Weekly, and W.-Y. Kim (2008), Seismic identification of along-axis hydrothermal flow on the East Pacific Rise, Nature, 451, 181-184, doi:10.1038/nature06424.

Tominaga, M., D. A. H. Teagle, J. C. Alt, and S. Umino (2009), Determination of the volcanostratigraphy of oceanic crust formed at superfast spreading ridge: Electrofacies analyses of ODP/IODP Hole 1256D, Geochem. Geophys. Geosyst., 10, Q01003, doi:10.1029/2008GC002143.

Vanko, D. A., and C. Laverne (1998), Hydrothermal anorthitization of plagioclase within the magmatic/hydrothermal transition at mid-ocean ridges; examples from deep sheeted dikes (Hole 504B, Costa Rica Rift) and a sheeted dike root zone (Oman Ophiolite), Earth Planet. Sci. Lett., 162(1-4), 27-43, doi:10.1016/S0012-821X(98)00155-1.

Von Damm, K. L. (1995), Controls on the chemistry and temporal variability of seafloor hydrothermal fluids, in Seafloor Hydrothermal Systems: Physical, Chemical, Biological, and Geological Interactions, Geophys. Monogr. Ser., vol. 91, edited by S. E. Humphris et al., pp. 222-247, AGU, Washington, D. C.

Wheat, C. G., and M. J. Mottl (2000), Composition of pore and spring waters from baby bare: Global implications of geochemical fluxes from a ridge flank hydrothermal system, Geochim. Cosmochim. Acta, 64, 629-642, doi:10.1016/ S0016-7037(99)00347-6.

Wilson, D. S., et al. (2003), Proceedings of the Ocean Drilling Program, Initial Reports, vol. 206, Ocean Drill. Program, College Station, Tex.

Wilson, D. S., et al. (2006), Drilling to gabbro in intact ocean crust, Science, 312, 1016-1020, doi:10.1126/science.1126090.

Zheng, Y. F. (1993), Calculation of oxygen isotope fractionation in anhydrous silicate minerals, Geochim. Cosmochim. Acta, 57, 1079-1092, doi:10.1016/0016-7037(93)90042-U. (Erratum, Geochim. Cosmochim. Acta, 57, 3199, doi:10.1016/ 0016-7037(93)90306-H, 1993.) 